\title{
The C. elegans pharynx: a model for organogenesis*
}

\author{
Susan E. Mango ${ }^{\S}$, Department of Oncological Sciences, Huntsman \\ Cancer Institute, University of Utah, Salt Lake City, UT 84112 USA
}

\section{Table of Contents}

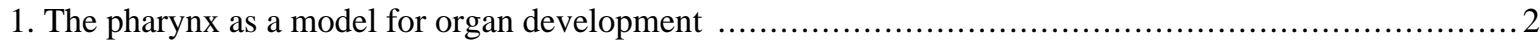

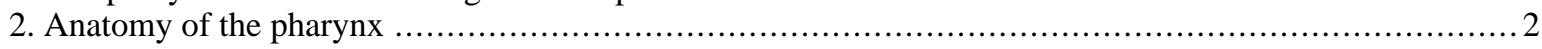

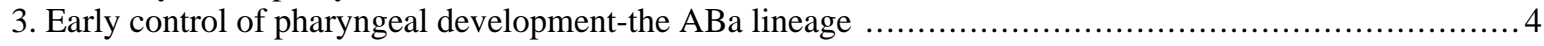

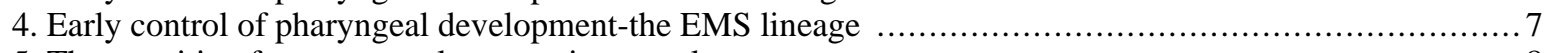

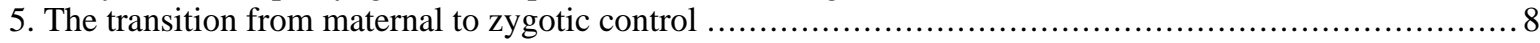

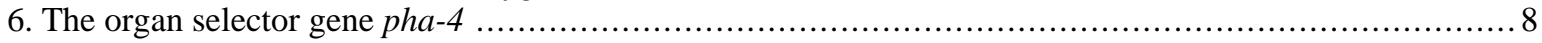

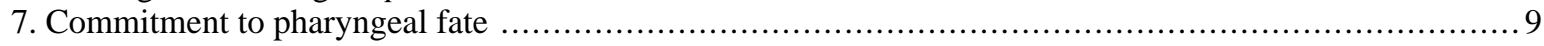

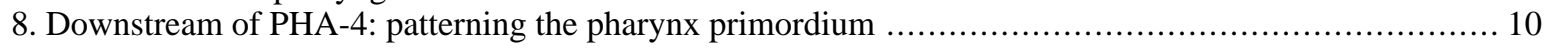

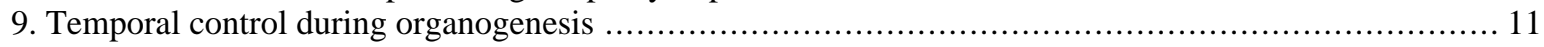

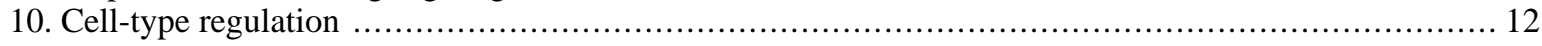

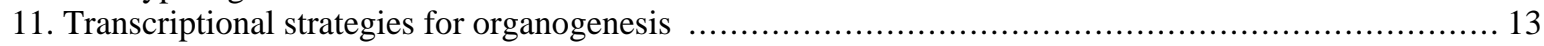

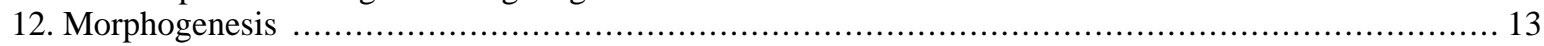

13. Epithelium formation-the pharyngeal arcade cells .................................................. 17

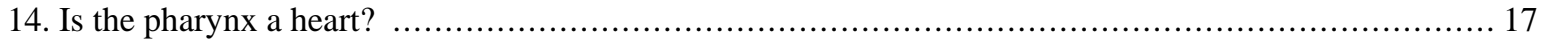

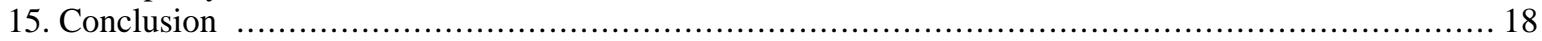

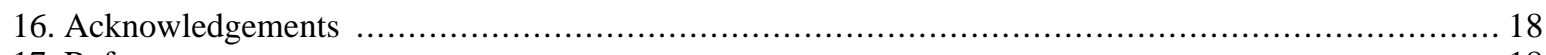

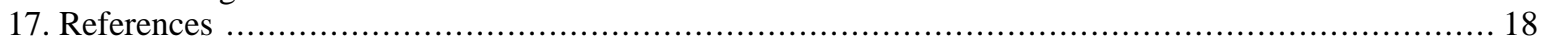

\begin{abstract}
The $C$. elegans foregut (pharynx) has emerged as a powerful system to study organ formation during embryogenesis. Here I review recent advances regarding cell-fate specification and epithelial morphogenesis during pharynx development. Maternally-supplied gene products function prior to gastrulation to establish pluripotent blastomeres. As gastrulation gets under way, pharyngeal precursors become committed to pharyngeal fate in a process that requires PHA-4/FoxA and the Tbox transcription factors TBX-2, TBX-35, TBX-37 and TBX-38. Subsequent waves of gene expression depend on the affinity of PHA-4 for its target promoters, coupled with combinatorial strategies such as feed-forward and positive-feedback loops. During later embryogenesis, pharyngeal precursors undergo reorganization and a mesenchymal-to-epithelial transition to form the linear gut tube. Surprisingly, epithelium formation does not depend on cadherins, catenins or integrins. Rather, the kinesin ZEN-4/MKLP1 and CYK-4/RhoGAP are critical to establish the apical domain during epithelial polarization. Finally, I discuss similarities and differences between the nematode pharynx and the vertebrate heart.
\end{abstract}

\footnotetext{
*Edited by Geraldine Seydoux and James R. Priess. Last revised November 7, 2006. Published January 22, 2007. This chapter should be cited as: Mango, S.E. The C. elegans pharynx: a model for organogenesis (January 22, 2007), WormBook, ed. The C. elegans Research Community, WormBook, doi/10.1895/wormbook.1.129.1, http://www.wormbook.org.

Copyright: ( 2007 Susan E. Mango. This is an open-access article distributed under the terms of the Creative Commons Attribution License, which permits unrestricted use, distribution, and reproduction in any medium, provided the original author and source are credited.

${ }^{\S}$ To whom correspondence should be addressed. E-mail: susan.mango@hci.utah.edu
} 


\section{The pharynx as a model for organ development}

Four characteristics of the $C$. elegans pharynx make it a powerful system to study organogenesis. First, $C$. elegans is transparent and the complete cell-lineage is known (Sulston et al., 1983), making it possible to follow organogenesis from the earliest stages of primordium formation to the terminal steps of differentiation and morphogenesis. Second, the mature pharynx is simple and well-characterized. It is composed of 95 nuclei that can be grouped into seven cell types. The position and morphology of these cells have been characterized at the ultrastructural level (Albertson and Thomson, 1976). In addition, there are antibodies and GFP reporters that mark individual cell types or developmental stages within the pharynx (http://www.wormbase.org/db/searches/ expr_search). These tools are invaluable for detailed studies of wildtype and mutant embryos at the level of individual cells. Third, pharynx development is robust. Embryos with abnormal development in other tissues can still produce a well-differentiated pharynx. For example, an embryo that cannot undergo normal morphogenesis arrests as a ball of cells with a differentiated pharynx (Ahnn and Fire, 1994; Chanal and Labouesse, 1997; Storfer-Glazer and Wood, 1994; Terns et al., 1997). This characteristic enables researchers to focus on molecules likely to play a direct role in pharynx formation without the problems associated with indirect effects. Fourth, formation of the pharynx faces similar developmental challenges to those of organs in more complex animals and uses conserved molecular pathways to meet those challenges. For example, the pharynx is composed of cells with different embryonic origins (Sulston et al., 1983), similar to the polyclonal origin of most vertebrate organs. The pha-4 locus (discussed below) is critical to specify pharyngeal identity, regardless of ancestry (Mango et al., 1994). The mammalian orthologues of pha-4 are the FoxA proteins, and, like pha-4, FoxA2 is essential for gut development in all organisms studied to date (Carlsson and Mahlapuu, 2002).

\section{Anatomy of the pharynx}

We have a detailed knowledge of the anatomy of the pharynx, based on ultrastructural studies by Donna Albertson (Albertson and Thomson, 1976). The pharynx is a bilobed, linear tube encased in a basement membrane. It can be subdivided into six sections, which are, from anterior to posterior, the buccal cavity, procorpus, metacorpus (anterior bulb), isthmus, terminal bulb and pharyngeal-intestinal valve (see Figure 1). I define the pharynx as those cells of the foregut that express PHA-4 and that are lost in pha-4 mutants, which includes two additional types of cells not encompassed by the pharyngeal basement membrane (arcade cells, pharyngeal intestinal valve cells; Horner et al., 1998; Mango et al., 1994). These criteria identify 95 nuclei that can be subdivided into seven cell types: arcade cells, muscles, epithelia, neurons, glands, marginal cells and valves (Albertson and Thomson, 1976). Along the longitudinal axis, there are eight sections of muscles and three sections of marginal cells; these make up the bulk of the pharynx (see Figure 2). Radially, the muscles and marginal cells are organized with three-fold symmetry around the pharyngeal lumen. These cells have characteristics of epithelia, with adherens junctions and an apical surface that faces the lumen (Albertson and Thomson, 1976). Posteriorly, a toroid of six valve cells connects pm8, the last pharyngeal muscle, to the intestine. Anteriorly, the pharynx attaches to the buccal cavity and exterior epidermis via nine arcade cells and nine epithelial cells, organized into three rings. Five gland cells and twenty neurons are embedded within the muscle/marginal cell epithelium. The neurons extend processes either dorsally or along the left and right subventral surfaces and synapse onto muscles or nerves. The gland cells contain processes that open into the pharyngeal lumen. The glands appear to secrete vesicles through these processes just before hatching, at each larval molt and during feeding. The nature of the secretions is unknown but may aid in degrading chitin and cuticle, and in digesting food. The pharyngeal lumen is lined with cuticle, which connects to the cuticle of the epidermis. Specialized fingers that project into the lumen of the terminal bulb may function as teeth or a sieve during feeding. For excellent images and an in-depth description of pharyngeal and epithelial morphology, see Wormatlas and the online WormBook. 


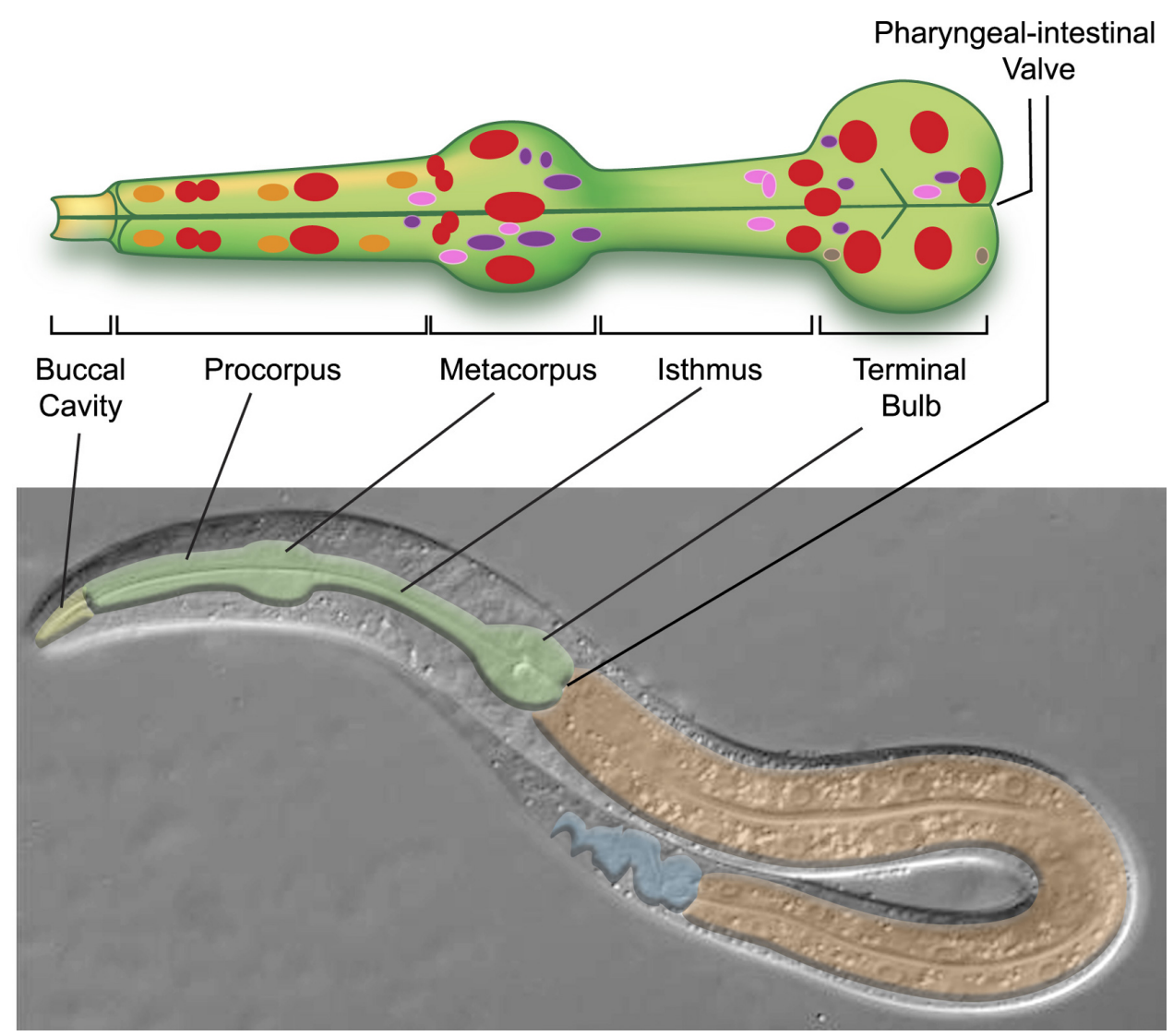

Figure 1. Nuclei of the pharynx. The C. elegans digestive tract is an epithelial tube consisting of the buccal cavity (lower panel, yellow), foregut or pharynx (green), midgut or intestine (orange) and hindgut (blue). Nuclei within the pharynx (upper panel) are shown as red muscles, purple neurons, orange epithelia, pink marginal cells and brown glands. Not shown: arcade cells and pharyngeal intestinal valves.
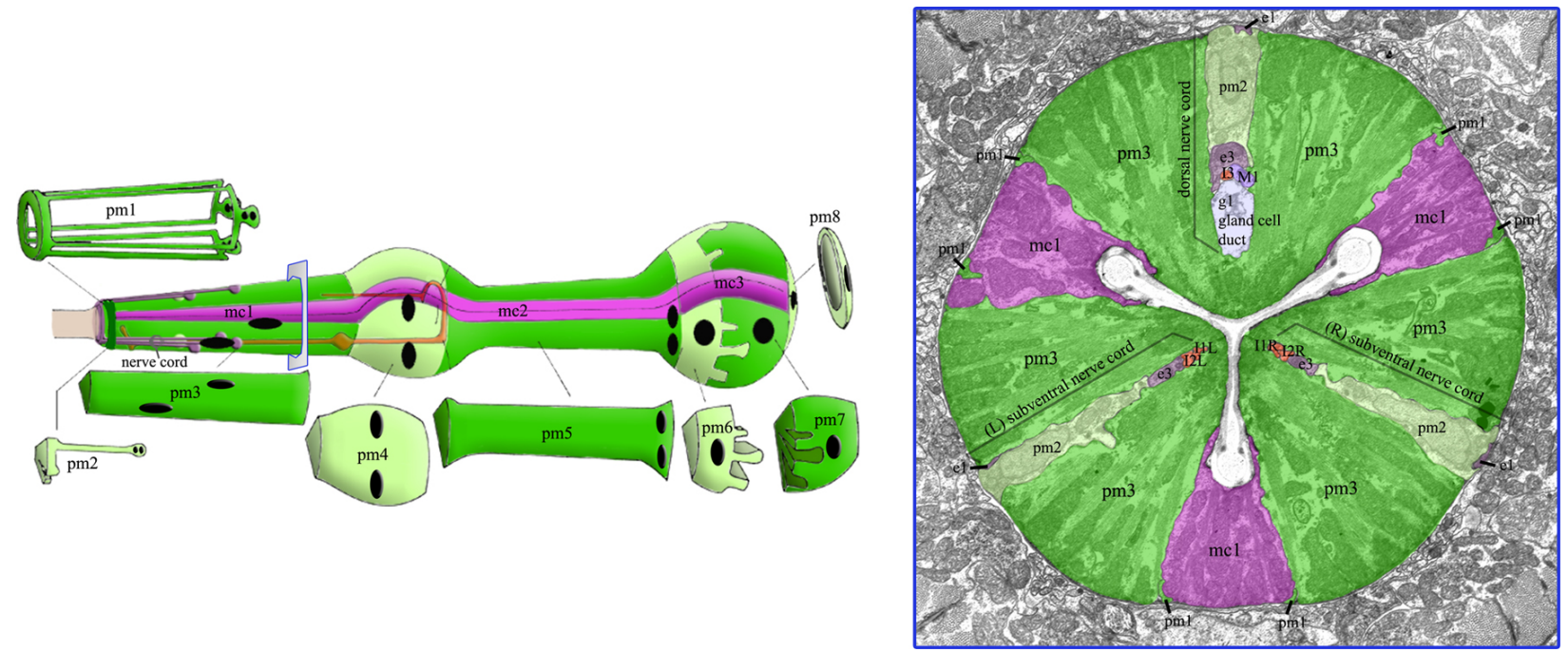

Figure 2. Pharynx anatomy. The pharynx is composed of eight layers of muscles (pm1-8, green) separated by structural marginal cells (mc1-3, pink). These are arranged with three-fold rotational symmetry, as shown in the cross section. Kindly reproduced with permission from Z.F. Altun \& D.H. Hall's Alimentary System in WormAtlas. Right-click or control click for high resolution image. 


\section{Early control of pharyngeal development-the ABa lineage}

The pharynx is generated polyclonally during embryogenesis: at the 4-cell stage, two blastomeres, $\mathrm{ABa}$ and EMS, contribute descendants to the pharynx, whereas their sisters do not (see Figure 3). Prior to gastrulation at the 28-cell stage, most early blastomeres are pluripotent and give rise to multiple cell types. For example, ABa and EMS each produces both pharyngeal cells and non-pharyngeal cells such as epidermis or body wall muscle (Sulston et al., 1983).

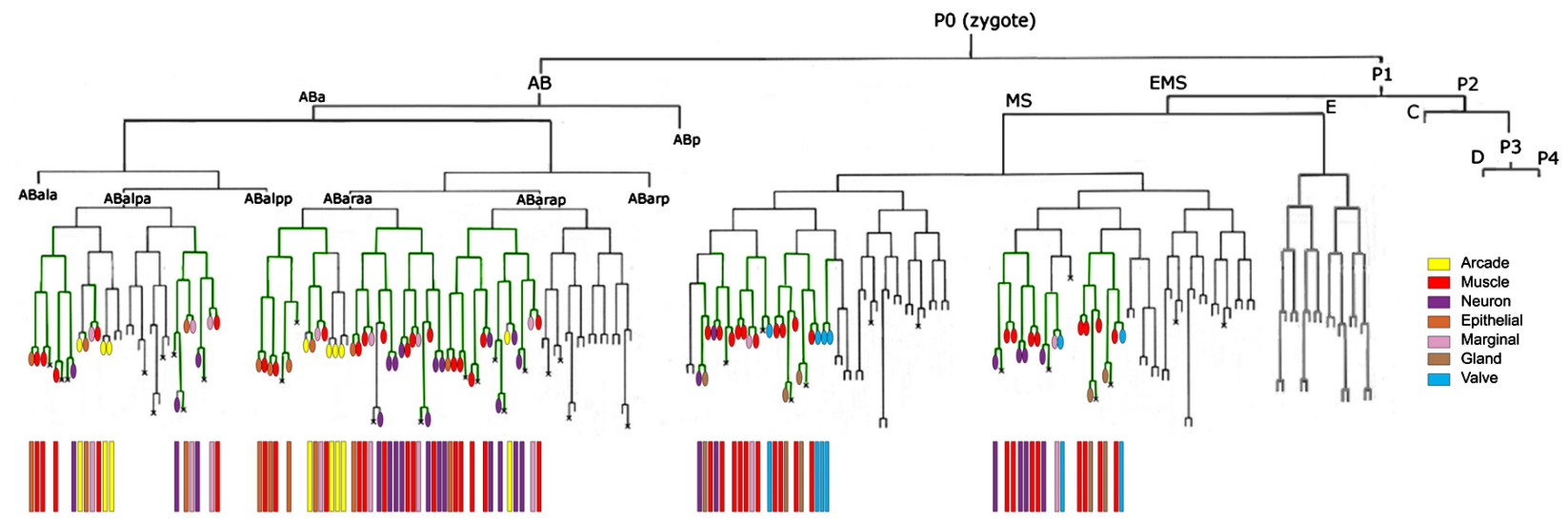

Figure 3. The pharynx is generated polyclonally. The $C$. elegans cell lineage, with emphasis on the sublineages that generate pharyngeal cells (green lines). Pharyngeal cell types are denoted by color: yellow arcade cells, red muscles, purple neurons, orange epithelia, pink marginal cells, brown glands and blue valves. Right-click or control click for high resolution image.

The production of pharyngeal cells by ABa and EMS depends on at least two distinct molecular pathways. The ABa pathway is dependent on intercellular signaling between blastomeres and on the Notch receptor orthologue glp-1 (see Figure 4 and Table 1; Priess et al., 1987; Priess and Thomson, 1987). glp-1 RNA is donated to the embryo by the mother (i.e., maternally) and is selectively translated in ABa and its sister ABp (Evans et al., 1994). Multiple events during embryogenesis depend on Notch signaling, and I focus only on those involved in pharyngeal development. An unidentified GLP-1 ligand generated by EMS descendents activates the LAG-1 transcription factor at the 12-15-cell stage (Christensen et al., 1996; Hutter and Schnabel, 1994; Lambie and Kimble, 1991; Mango et al., 1994; Moskowitz et al., 1994). LAG-1 in turn activates the organ selector gene pha-4 (Smith and Mango, 2006), described below, and the REF-1 family of bHLH transcription factors (Neves and Priess, 2005). The REF-1 family is comprised of six genes distantly related to the $E(s p l)$ family of repressors: ref-1, hlh-25, hlh-26, hlh-27, hlh-28, hlh-29. Each gene contains two bHLH domains and a basic region. However, these factors lack other sequences typically found in $E(s p l)$ proteins, such as the Orange domain and the terminal W/YRPW sequence (Neves and Priess, 2005). In other species, this motif mediates binding to co-repressors. Thus, it is uncertain how REF-1 family members recruit co-repressors such as UNC-37/groucho, although genetic evidence supports a repressor function (Neves and Priess, 2005). 
Table 1. Summary of genes involved in pharynx development. Genes implicated in pharynx development are listed from earliest stages of specification to later events. Aph: anterior pharynx absent Daf: dauer defective, M/Z: maternal or zygotic contribution of RNA or protein, Pha: pharynx absent, pm: pharyngeal muscle, PPa: posterior pharynx absent, Pun: pharynx unattached, Rcp: receptor, TF: transcription factor, Zn: zinc, ?: unknown.

\begin{tabular}{|c|c|c|c|c|c|c|c|c|}
\hline Gene & \begin{tabular}{|l|} 
Homology \\
\end{tabular} & $\mathbf{M} / \mathbf{Z}$ & $\begin{array}{l}\text { Expression } \\
\text { (initiation) }\end{array}$ & $\begin{array}{c}\text { Pha } \\
\text { phenotype }\end{array}$ & Targets & $\begin{array}{c}\text { Binding } \\
\text { sequence }\end{array}$ & \begin{tabular}{|c|} 
Upstream \\
genes
\end{tabular} & References \\
\hline glp-1 & Notch Rcp & $\mathrm{M}$ & ABa@4 & Aph & $\begin{array}{l}\text { ref-1 } \\
\text { pha-4 }\end{array}$ & N/A & $?$ & $\begin{array}{l}\text { Kalb et al., 1998; } \\
\text { Mango et al., 1994; } \\
\text { Priess et al., } 1987\end{array}$ \\
\hline lag-1 & $\mathrm{Su}(\mathrm{H}) \mathrm{TF}$ & $\mathrm{M}$ & Broadly & Aph & $\begin{array}{l}\text { ref-1 } \\
\text { pha-4 }\end{array}$ & RTGGGAA & glp-1 & $\begin{array}{l}\text { Christensen et al., } \\
\text { 1996; Smith and } \\
\text { Mango, 2006 }\end{array}$ \\
\hline$s k n-1$ & Zipper TF & $\mathrm{M}$ & EMS@4 & Pha & $\begin{array}{l}\text { ref-1 } \\
\text { end-1 }\end{array}$ & \begin{tabular}{|c|} 
G/ATCAT + \\
$\mathrm{A} / \mathrm{T}$
\end{tabular} & $?$ & $\begin{array}{l}\text { Bowerman et al., } \\
\text { 1992; Maduro et al., } \\
\text { 2005b; Mango et al., } \\
\text { 1994; Neves and } \\
\text { Priess, } 2005\end{array}$ \\
\hline med-1/2 & \begin{tabular}{|l|} 
GATA-like \\
Zn TF
\end{tabular} & $\mathrm{M}, \mathrm{Z}$ & $\begin{array}{l}\text { EMS@4 } \\
\text { and } \\
\text { maternal }\end{array}$ & Ppa & $\begin{array}{l}\text { end-1/3 } \\
\text { hlh-25 }\end{array}$ & $\begin{array}{l}\text { RRRAGT- } \\
\text { ATAC }\end{array}$ & $s k n-1$ & $\begin{array}{l}\text { Broitman-Maduro et } \\
\text { al., 2005; Maduro et } \\
\text { al., 2001 }\end{array}$ \\
\hline ref-1 & bHLH TF & $\mathrm{Z}$ & $\begin{array}{c}\mathrm{ABa} @ 26 \\
\mathrm{ABp} @ 4 \\
\mathrm{EMS} @ 24\end{array}$ & none & $\begin{array}{c}t b x-37 \\
t b x-2\end{array}$ & CANNTG & lag-1 & $\begin{array}{l}\text { Neves and Priess, } \\
\text { 2005; Smith and } \\
\text { Mango, } 2006\end{array}$ \\
\hline$t b x-37 / 38$ & T-box & $\mathrm{Z}$ & ABa@24 & Aph & pha-4? & $?$ & $\begin{array}{l}r e f-1 \text { in } \\
\text { some cell } \\
\text { types }\end{array}$ & Good et al., 2004 \\
\hline pha-4 & FoxA & $\mathrm{Z}$ & $\begin{array}{l}\mathrm{ABa} @ 44 \\
\mathrm{MS} @ 28\end{array}$ & Pha & many & TRTTKRY & \begin{tabular}{|c|} 
lag-1 \\
tbx-37/38 \\
med-1/2 \\
glp-1
\end{tabular} & $\begin{array}{l}\text { Gaudet and Mango, } \\
\text { 2002; Good et al., } \\
\text { 2004; Maduro et al., } \\
\text { 2005b; Mango et al., } \\
\text { 1994; Smith and } \\
\text { Mango, } 2006\end{array}$ \\
\hline$h t z-1$ & $\begin{array}{l}\text { H2A.Z } \\
\text { histone } \\
\text { variant }\end{array}$ & $\mathrm{Z}$ & $\begin{array}{l}\text { Broadly } \\
\text { from the } \\
28 \text {-cell } \\
\text { stage }\end{array}$ & $\begin{array}{c}\text { Delayed } \\
\text { activation }\end{array}$ & $\begin{array}{l}\text { myo-2, } \\
\text { R07B1.9 }\end{array}$ & N/A & $?$ & $\begin{array}{l}\text { Updike and Mango, } \\
2006\end{array}$ \\
\hline$t b x-2$ & T-box & $\mathrm{Z}$ & ABa@8E & $\begin{array}{c}\mathrm{ABa} \\
\text { muscles } \\
\text { absent }\end{array}$ & $\begin{array}{c}\text { pha-4 } \\
\text { ceh-22? }\end{array}$ & $?$ & \begin{tabular}{|} 
ref-1 in \\
some cells \\
tbx-37/38?
\end{tabular} & $\begin{array}{l}\text { Chowdhury et al., } \\
\text { 2006; Smith and } \\
\text { Mango, } 2006\end{array}$ \\
\hline ceh-22 & \begin{tabular}{|c|} 
Nkx2-5 \\
Homeobox \\
TF
\end{tabular} & $\mathrm{Z}$ & $\begin{array}{l}\text { pm3-5, } \\
\text { pm7 }\end{array}$ & $\begin{array}{l}\text { Indistinct } \\
\text { BM } \\
\text { Around } \\
\text { pharynx }\end{array}$ & myo-2 & CACTTAT & $\begin{array}{l}\text { pha-4 } \\
\text { ceh-22 } \\
\text { ceh-2 } \\
\text { pha-2 }\end{array}$ & $\begin{array}{l}\text { Kalb et al., 1998; } \\
\text { Mango et al., 1994; } \\
\text { Okkema and Fire, } \\
\text { 1994; Okkema et al., } \\
1997\end{array}$ \\
\hline peb-1 & \begin{tabular}{|c|} 
FLYWCH \\
Zn TF
\end{tabular} & $\mathrm{Z}$ & Broadly & $\begin{array}{c}\text { Glands } \\
\text { distended }\end{array}$ & myo-2 & YDTGCCRW & $?$ & $\begin{array}{l}\text { Beaster-Jones and } \\
\text { Okkema, 2004; } \\
\text { Thatcher et al., } 2001\end{array}$ \\
\hline daf-12 & $\begin{array}{c}\text { NHR Zn } \\
\text { TF }\end{array}$ & $\mathrm{Z}$ & Broadly & Daf & $\begin{array}{l}\text { myo-2 } \\
\text { ceh-22 }\end{array}$ & AGTGCA & $d a f-9$ & Ao et al., 2004 \\
\hline
\end{tabular}


The C. elegans pharynx: a model for organogenesis

\begin{tabular}{|c|c|c|c|c|c|c|c|c|}
\hline Gene & Homology & $\mathbf{M} / \mathbf{Z}$ & \begin{tabular}{|l|}
$\begin{array}{l}\text { Expression } \\
\text { (initiation) }\end{array}$ \\
\end{tabular} & $\begin{array}{c}\text { Pha } \\
\text { phenotype }\end{array}$ & Targets & $\begin{array}{c}\text { Binding } \\
\text { sequence }\end{array}$ & $\begin{array}{l}\text { Upstream } \\
\text { genes }\end{array}$ & References \\
\hline pha-1 & Novel & $\mathrm{Z}$ & Broadly & \begin{tabular}{|c|} 
Arrested \\
diffn, loss \\
of TF \\
expression
\end{tabular} & $\begin{array}{l}\text { ceh-22 } \\
\text { pha-4 }\end{array}$ & NA or? & $?$ & $\begin{array}{l}\text { Fay et al., 2004; } \\
\text { Granato et al., 1994; } \\
\text { Schnabel and } \\
\text { Schnabel, } 1990\end{array}$ \\
\hline pha-2 & Homeobox & $\mathrm{Z}$ & $\begin{array}{l}\text { Pm5, I4, } \\
\text { epi }\end{array}$ & $\begin{array}{c}\text { pm4, pm5 } \\
\text { morph }\end{array}$ & $\begin{array}{l}\text { ceh-22 } \\
\text { ceh-2 }\end{array}$ & & & $\begin{array}{l}\text { Avery, 1993; Morck } \\
\text { et al., 2004 }\end{array}$ \\
\hline ast-1 & ETS & $\mathrm{Z}$ & Head & Pun & $?$ & $?$ & $?$ & Schmid et al., 2006 \\
\hline myo-2 & $\begin{array}{l}\text { Myosin } \\
\text { Heavy } \\
\text { chain }\end{array}$ & $\mathrm{Z}$ & pm1-pm8 & & & NA & $\begin{array}{l}\text { pha-4 } \\
\text { ceh- } 22 \\
\text { peb-1 } \\
\text { daf-12 } \\
\text { daf-3 }\end{array}$ & $\begin{array}{l}\text { Ao et al., 2004; } \\
\text { Gaudet and Mango, } \\
\text { 2002; Mango et al., } \\
\text { 1994; Okkema and } \\
\text { Fire, 1994; Thatcher } \\
\text { et al., 2001 }\end{array}$ \\
\hline unc-39 & $\operatorname{six} 4 / 5$ & $\mathrm{Z}$ & $\begin{array}{c}\text { Mesoderm } \\
\text { Arc }\end{array}$ & \begin{tabular}{|c|} 
Pun \\
metacorpus
\end{tabular} & $?$ & $?$ & $?$ & $\begin{array}{l}\text { Yanowitz et al., } \\
2004\end{array}$ \\
\hline eya-1 & $\begin{array}{l}\text { Eyes } \\
\text { absent }\end{array}$ & $\mathrm{Z}$ & $\begin{array}{c}\text { Broadly } \\
\geq \text { bean }\end{array}$ & \begin{tabular}{|c|} 
Thin, \\
asymmetric
\end{tabular} & $?$ & NA & $?$ & Furuya et al., 2005 \\
\hline$u b c-9$ & $\begin{array}{l}\text { E2 sumo } \\
\text { ligase }\end{array}$ & ? & ? & $\begin{array}{c}\mathrm{ABa} \\
\text { muscles } \\
\text { absent }\end{array}$ & $?$ & NA & ? & $\begin{array}{l}\text { Chowdhury et al., } \\
2006\end{array}$ \\
\hline gei-17 & $\begin{array}{l}\text { E3 sumo } \\
\text { ligase }\end{array}$ & ? & $?$ & $\begin{array}{l}\text { Thick } \\
\text { isthmus }\end{array}$ & $?$ & NA & $?$ & $\begin{array}{l}\text { Chowdhury et al., } \\
2006\end{array}$ \\
\hline ceh-24 & Nkx TF & $\mathrm{Z}$ & pm8 & None & $?$ & $?$ & $?$ & Harfe et al., 1998 \\
\hline ceh-2 & $\begin{array}{l}\text { Homeobox } \\
\text { ems, EMX }\end{array}$ & $\mathrm{Z}$ & $\begin{array}{l}\text { I3, NSM, } \\
\text { M3, pm2, } \\
\text { e2 }\end{array}$ & $\begin{array}{c}\text { Poor } \\
\text { feeding, } \\
\text { M3 } \\
\text { defective }\end{array}$ & & $?$ & $?$ & Aspock et al., 2003 \\
\hline ceh-43 & $\begin{array}{l}\text { Distal-less } \\
\text { homeobox }\end{array}$ & $\bar{Z}$ & $\begin{array}{l}\text { Non-pha } \\
\text { neurons, } \\
\text { epidermis }\end{array}$ & $\begin{array}{c}\text { Pun, } \\
\text { anterior } \\
\text { leakage }\end{array}$ & & & & $\begin{array}{l}\text { Aspock and Burglin, } \\
\text { 2001; Burglin and } \\
\text { Aspock, } 1999\end{array}$ \\
\hline
\end{tabular}

One of the REF-1 downstream targets, direct or indirect, is a pair of T-box genes called $t b x-37$ and $t b x-38$. TBX-37 and TBX-38 constitute a pair of closely related, redundant factors that are activated at the 24-cell stage in the eight $\mathrm{ABa}$ descendents and required for a subset of these cells to generate pharynx (Good et al., 2004). Their restricted expression within these cells depends on repression by REF-1 family members, since inactivation of REF-1 family genes leads to widespread TBX-37/38 in blastomeres that normally would never normally express these genes (Neves and Priess, 2005). Within ABa-derived cells destined to form the pharynx, initiation of TBX-37/38 expression precedes REF-1 activity, which explains why GLP-1 activity does not block pharyngeal development in this subset of cells. The T-box family of transcription factors are defined by the T-box DNA binding domain, and can function as either activators or repressors (Wilson and Conlon, 2002). There are at least 20 T-box transcription factors in the C. elegans genome and surprisingly, several of them function as redundant pairs e.g., $t b x-37$ and $t b x-38, t b x-8$ and $t b x-9$ (Andachi, 2004; Good et al., 2004; Pocock et al., 2004). The combination of Notch signaling and TBX-37/38 function activate the organ selector gene pha-4/FoxA to initiate pharyngeal development (Good et al., 2004; Kalb et al., 1998; Mango et al., 1994). Thus, selectivity of pha-4 activation within the AB lineage depends on the co-incidence of two distinct cues-GLP-1/Notch and TBX-37/38. For additional discussion on Notch Signaling, see Notch signaling in the C. elegans embryo. For more information on transcription factors see chapters by Okkema and Krause, and Blackwell and Walker in the Molecular biology section of WormBook. 


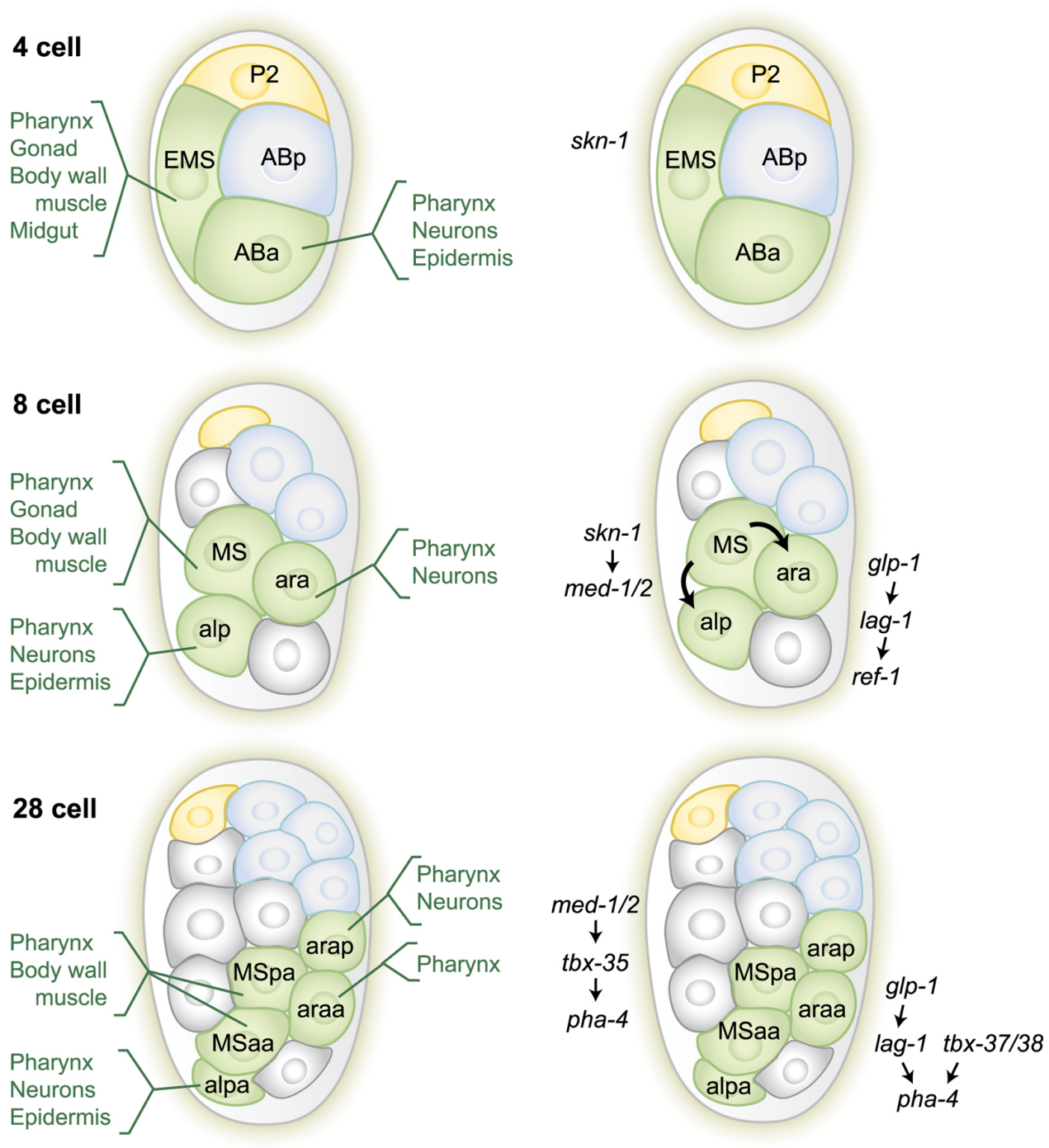

Figure 4. Early pharyngeal development. Features of pharyngeal development from the 4-cell stage to the 28-cell stage. This period is under control of maternal factors, but transitions to zygotic control with the activation of $t b x-35, t b x-37, t b x-38$ and $p h a-4$. Left panels show cells and the cell types they produce. Right panels illustrate genetic regulatory relationships. The pharynx is generated from green blastomeres (ABa and EMS at the 4-cell stage). Descendents of green cells that do not produce pharyngeal cells are grey.

\section{Early control of pharyngeal development-the EMS lineage}

The EMS pathway of pharyngeal development does not require $g l p-1$ signals (see Figure 4; Good et al., 2004; Priess et al., 1987; Priess and Thomson, 1987). Rather, EMS depends on the activity of two other maternal genes to generate pharyngeal cells, namely skn-1 and pop-1 (Bowerman et al., 1992; Lin et al., 1995). skn-1 encodes an bZIP-related transcription factor that functions at the 4-8 cell stage to specify the EMS blastomere (Bowerman et al., 1993; Bowerman et al., 1992). In the absence of $s k n-1$, no pharynx is produced because EMS descendents are transformed into their cousin, the $\mathrm{C}$ blastomere, and $\mathrm{C}$ does not generate Notch ligands to signal to $\mathrm{ABa}$. pop-1 encodes a Tcf/Lef-1 homolog that is enriched in the nucleus of a daughter of EMS, called MS, by the action of the wingless signalling pathway and lit-1 kinase (Lin et al., 1995; Lo et al., 2004). When pop-1 activity is reduced, MS develops like E and MS-derived pharyngeal cells are lost (Lin et al., 1995). E can produce pharyngeal-inducing cues and so the anterior pharynx is still made. The role of POP-1 in MS is to repress genes that promote E fate (Broitman-Maduro et al., 2005; Calvo et al., 2001; Maduro et al., 2002; Shetty et al., 2005).

The MS and E blastomeres also express the GATA-like factors med-1 and med-2 at the 7-cell stage. The med gene products are contributed maternally (Maduro et al., 2006) and are also activated by SKN-1 (Maduro et al., 
The C. elegans pharynx: a model for organogenesis

2006; Maduro et al., 2001). Loss of both med genes leads to conversion of MS fate into that of C, leading to loss of the posterior pharynx (Goszczynski and McGhee, 2005; Maduro et al., 2006; Maduro et al., 2001). There is currently debate regarding the contribution of the MED factors, with one report suggesting few embryos have an MS to $\mathrm{C}$ fate transformation (Goszczynski and McGhee, 2005) and other studies suggesting a greater proportion of embryos are affected (Maduro et al., 2006; Maduro et al., 2001). The MED factors bind the consensus sequence RAGTATAC, which differs from the canonical GATA site WGATAR. Strikingly, a search of the genome for MED consensus sites accurately predicted many MED factor target genes. Among these targets were multiple transcription factors: $t b x-35$, sox-1, hlh-25, hlh-27, hlh-28, and hlh-29 (Broitman-Maduro et al., 2005). One of these, tbx-35, is expressed within MS descendants, and is required to produce the bulk of body wall muscles and pharyngeal cells by MS descendants (Broitman-Maduro et al., 2006). Intriguingly, $t b x-35$ is closely related to $t b x-37$ and $t b x-38$, revealing a similar requirement for Tbox factors for both $\mathrm{ABa}$ and MS pharyngeal development. A second target of SKN-1 within MS are ref-1 family members, which may repress TBX-37/38 in these cells (Neves and Priess, 2005).

\section{The transition from maternal to zygotic control}

LAG-1, TBX-35, TBX-37/38 and the MED factors initiate the zygotic phase of pharyngeal development. The phenotypes associated with the zygotic regulators differ from those observed with the maternal genes. In glp- 1 , skn-1 and pop-1 embryos, all of the cell types that normally derive from a given blastomere are affected, not just pharyngeal cells. In these mutant embryos, $\mathrm{ABa}$ or EMS descendants follow the cell lineage and differentiation patterns characteristic of other early blastomeres (Bowerman et al., 1992; Hutter and Schnabel, 1994; Lin et al., 1995; Priess et al., 1987). These phenotypes suggest that early blastomeres acquire unique identities that are specified by maternal genes like glp-1, skn-1 and pop-1. By contrast, later in development, cells that are destined to make the pharynx and that derive from different cell lineages, coordinate their development to form an integrated, functioning structure. The genes that function during these later processes have phenotypes that affect a specific tissue or organ rather than a cell lineage, for example, pha-4, ceh-22, tbx-2 (Chowdhury et al., 2006; Mango et al., 1994; Okkema and Fire, 1994; Okkema et al., 1997; Smith and Mango, 2006). LAG-1, TBX-35, TBX-37/38 and the MED factors contribute to the transition from maternal to zygotic control-their mutant phenotypes affect cell lineages, but their target genes, described below, are geared towards forming tissues and organs (Broitman-Maduro et al., 2006; Good et al., 2004; Maduro et al., 2005a; Smith and Mango, 2006).

Whereas $\mathrm{ABa}$ and EMS are pluripotent, their descendants become lineally restricted (see Figure 3). Around the 200 cell stage, $\mathrm{ABa}$ and EMS descendants are born that will produce either all pharyngeal cells or no pharyngeal cells (Sulston et al., 1983). The lineage restriction seen at this time applies to pharyngeal fate generally, not to individual cell types found within the pharynx. For example, one particular pharyngeal precursor born at the 200-cell stage (ABaraaapa) divides twice to generate four pharyngeal cells: one muscle, one epithelial cell, one arcade cell and one marginal cell (Sulston et al., 1983). This separation of pharyngeal and non-pharyngeal cell lineages was the first clue that cells acquire a general pharyngeal organ identity.

\section{The organ selector gene pha-4}

The central regulator of pharynx development is pha-4, a FoxA transcription factor (Horner et al., 1998; Kalb et al., 1998; Mango et al., 1994). No pharyngeal primordium is formed in embryos lacking pha-4, and at least a proportion of pharyngeal cells develop into ectoderm, which can be visualized by the ectodermal markers LIN-26 and ELT-3 (Horner et al., 1998; Labouesse and Mango, 1999; Kiefer et al., 2006). Conversely, expression of pha-4 throughout the embryo can induce pharyngeal fate in a subset of embryonic blastomeres (Horner et al., 1998; Labouesse and Mango, 1999). No zygotic gene besides pha-4 has been found that can mutate to a pharynx-less phenotype (S. Mango, unpublished, J. Priess, pers. comm., J. Rothman, pers. comm.), suggesting that the maternal $\mathrm{ABa}$ and MS pathways converge on pha-4. Thus, pha-4 behaves as an organ selector gene (Mann and Carroll, 2002) that specifies pharynx identity for both $\mathrm{ABa}$ and MS-derived blastomeres.

Transcription of pha-4 is activated at the 28-cell stage in MS descendants, the 44-cell stage in ABa descendents (Baugh et al., 2003; Good et al., 2004; Horner et al., 1998; Smith and Mango, 2006) and continues to be expressed in all pharyngeal cells throughout life (Alder et al., 2003; Azzaria et al., 1996; Horner et al., 1998; Kalb et al., 1998). pha-4 is also expressed in midgut and hindgut cells, at varying levels, and is required to generate anterior hindgut cells vir and rep (Mango et al., 1994). In the pharynx, the timing of activation suggests that pha-4 may be regulated directly by LAG-1 and TBX-37/38 within ABa descendents at the 24-cell stage (Good et al., 2004), and TBX-35 in the MS lineage (Broitman-Maduro et al., 2006). However, it is likely that additional, undiscovered regulators exist. 


\section{Commitment to pharyngeal fate}

When do embryonic cells commit to pharyngeal fate? Three observations suggest that embryonic cells are pluripotent up to the 4E stage (equivalent to 50-100 cells; embryos are staged by the number of endodermal or $\mathrm{E}$ cells), but subsequently lose their plasticity. First, at the $2 \mathrm{E}$ stage and earlier, individual blastomeres contribute to multiple cell types, as revealed by the C. elegans cell lineage (Sulston et al., 1983). One cell division later (4E stage, 50-100 cells), many cells give rise to descendants that contribute to only a single tissue or organ. Second, blastomeres at the $2 \mathrm{E}$ and $4 \mathrm{E}$ stages can adopt alternate fates in response to forced ubiquitous expression of heterologous cell fate regulators (Fukushige and Krause, 2005; Horner et al., 1998; Labouesse and Mango, 1999; Zhu et al., 1998; Kiefer et al., 2006). However, early blastomeres can no longer adopt alternate fates when challenged with an ectopic cell-fate regulator at $\geq 8 \mathrm{E}$ stage (Labouesse and Mango, 1999; Kiefer et al., 2006). Third, most genes required for cell identity are expressed by the 4-8E stage. These include $s k n-1$, pha-4, med-1/2, tbx-35, $t b x-37 / 38$ and $t b x-2$ (Bowerman et al., 1992; Chowdhury et al., 2006; Good et al., 2004; Horner et al., 1998; Priess et al., 1987; Smith and Mango, 2006). Genes expressed later often have subtler phenotypes involving morphology or differentiation, (e.g., ceh-22, pha-1, ceh-24 (Fay et al., 2004; Harfe et al., 1998; Okkema and Fire, 1994; Okkema et al., 1997; Schnabel and Schnabel, 1990). A temperature-sensitive configuration of pha-4 (Kaltenbach et al., 2005) revealed that reduction of pha-4 before the 4E-stage led to loss of pharyngeal identity whereas inactivation of pha-4 at later stages affected morphogenesis but not pharyngeal fate (Kiefer et al., 2006). These observations suggest that cells transition from pluripotent to committed at approximately the $4-8 \mathrm{E}$ stage.

Three strategies ensure that embryonic blastomeres develop into pharyngeal cells and do not stray towards another identity (see Figure 5). The first is positive feedback loops between pairs of pharyngeal regulators. For example, a positive regulatory loop between PHA-4 and TBX-2 contributes to production of pharyngeal muscles. TBX-2 expression initiates at the 8E stage and is required to maintain PHA-4 expression within ABa-derived pharyngeal muscle precursors (Chowdhury et al., 2006; Smith and Mango, 2006). Loss of either pha-4 or tbx-2 leads to reduced expression of the other transcription factor and absence of ABa-derived pharyngeal muscles. In other animals, TBX-2 orthologues function as repressors (Naiche et al., 2005) and, in C. elegans, TBX-2 interacts with components of the SUMO-conjugating pathway by yeast two hybrid (Chowdhury et al., 2006). In other organisms, SUMO is a repressive mark for transcription (Gill, 2005). Thus, it is unclear whether the positive regulatory loop between PHA-4 and TBX-2 reflects direct activation or indirect effects.
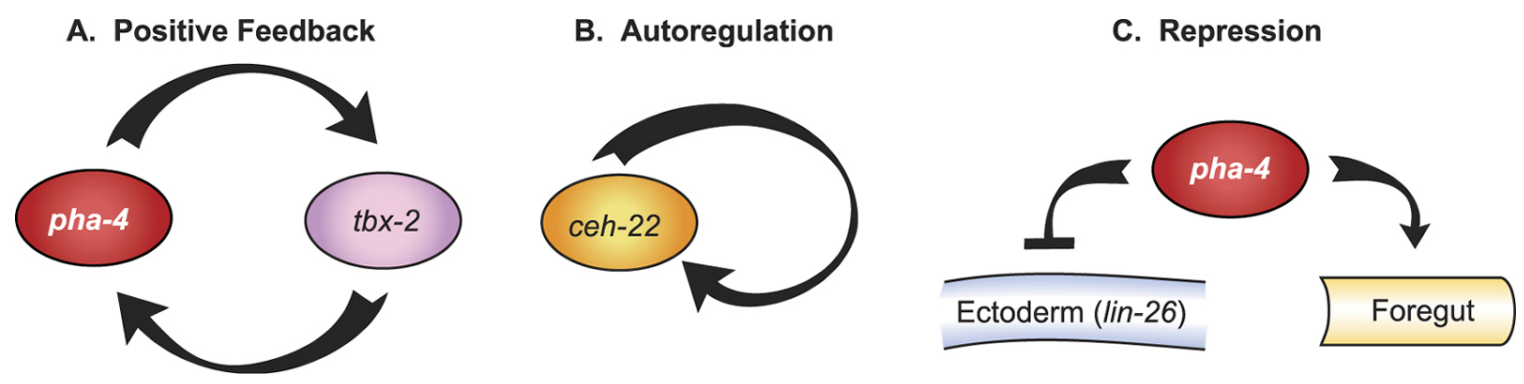

Figure 5. Strategies for cell fate commitment. Commitment to pharyngeal fate depends on A. positive feedback loops, B. positive autoregulation and C. repression of alternative fates.

A second strategy for cell fate commitment is auto-regulation (see Figure 5). For example, ceh-22 contains two enhancer elements, distal and proximal, which control initiation and maintenance of ceh-22 expression, respectively (Kuchenthal et al., 2001; Vilimas et al., 2004). The proximal enhancer carries a CEH-22 binding site that is necessary and sufficient for activity. Thus, maintenance of ceh-22 transcription depends on positive autoregulation through the proximal enhancer, which likely contributes to robust, stable ceh-22 expression and pharyngeal muscle fate.

The third strategy for cell fate commitment is transcriptional repression, which is important to inhibit alternative cell fates (see Figure 5). pha-4 is necessary and sufficient to inhibit ectodermal fate, and inhibits expression of ectodermal genes such as lin-26 or elt-3 (Horner et al., 1998; Kiefer et al., 2006). The lin-26 locus contains the CISg regulatory element, which is peppered with consensus, conserved PHA-4 sites (Landmann et al., 2004), and which binds PHA-4::YFP within pharyngeal cells, suggesting repression by PHA-4 could be direct (Kiefer et al., 2006). Repression of ectodermal fate also requires the NuRD complex and the TRIM factor TAM-1, which associates with PHA-4 in yeast two-hybrid assays (Kiefer et al., 2006; Li et al., 2004). Intriguingly, other 
The C. elegans pharynx: a model for organogenesis

proteins bearing a TRIM motif or RING finger domain mediate transcriptional repression via binding to the NuRD subunit Mi-2, suggesting a possible link between these factors (Shimono et al., 2003).

\section{Downstream of PHA-4: patterning the pharynx primordium}

How are individual cell types generated within the pharynx? This question has been difficult to address because the phenotypes associated with loss of individual pharyngeal cells can be subtle. Moreover, there appears to be significant redundancy for the underlying molecular mechanisms. Redundancy can be at the level of gene duplication (e.g., the six REF-1 family members; Neves and Priess, 2005) or at the level of pathways for non-homologous genes (e.g., ceh-22/Nkx2.5 and pha-1/DUF1114 (Okkema et al., 1997)). For these reasons, reverse genetics and genomic approaches will likely be very useful for deciphering the regulatory network that governs the latter stages of pharyngeal development (Table 2).

Table 2. Algorithms. Tools for genomic approaches to transcription control: Algorithms that can be used to identify potential regulatory sequences for known or novel transcription factors, to construct regulatory pathways or analyze microarrays.

\begin{tabular}{|c|c|c|l|}
\hline Name & URL & Use & References \\
\hline BioProspector & $\begin{array}{c}\text { http://ai.stanford.edu/ Xsliu/ } \\
\text { BioProspector/ }\end{array}$ & $\begin{array}{c}\text { Find enriched sequence motifs } \\
\text { via Gibbs sampling and Markov } \\
\text { models }\end{array}$ & Liu et al., 2001 \\
\hline BioTapestry & $\begin{array}{c}\text { http://labs.systemsbiology.net/ } \\
\text { bolouri/software/BioTapestry/ }\end{array}$ & $\begin{array}{c}\text { Visualization of gene regulatory } \\
\text { networks }\end{array}$ & $\begin{array}{l}\text { Longabaugh et al., } \\
\text { 2005 }\end{array}$ \\
\hline CisOrtho & http://dev.wormbase.org/CisOrtho/ & $\begin{array}{c}\text { Identify conserved targets of } \\
\text { worm transcription factors } \\
\text { whose DNA binding specificity } \\
\text { is known }\end{array}$ & Bigelow et al., 2004 \\
\hline ClusterBuster & http://cagt.bu.edu/page/ & $\begin{array}{c}\text { Identify clusters of pre-specified } \\
\text { motifs in nucleotide sequences }\end{array}$ & Frith et al., 2003 \\
\hline Co-Bind & $\begin{array}{c}\text { http://ural.wustl.edu/software.html } \\
\text { Compare }\end{array}$ & $\begin{array}{c}\text { Identify target sites for } \\
\text { cooperatively binding } \\
\text { transcription factors }\end{array}$ & GuhaThakurta and \\
Stormo, 2001
\end{tabular}


The C. elegans pharynx: a model for organogenesis

\begin{tabular}{|c|c|c|c|}
\hline Name & URL & Use & References \\
\hline ModuleFinder & $\begin{array}{l}\text { http://the_brain.bwh.harvard.edu/ } \\
\text { PSB2005MFSuppl/index.html }\end{array}$ & $\begin{array}{l}\text { Evaluate the likelihood that a } \\
\text { genomic region is a cis } \\
\text { regulatory module for an input } \\
\text { set of transcription factors } \\
\text { according to: homotypic site } \\
\text { clustering; heterotypic site } \\
\text { clustering; and evolutionary } \\
\text { conservation }\end{array}$ & Philippakis et al., 2005 \\
\hline MultiFinder & $\begin{array}{c}\text { http://the_brain.bwh.harvard.edu/ } \\
\text { multifinder.html }\end{array}$ & $\begin{array}{l}\text { Motif search using AlignACE, } \\
\text { MDscan, BioProspector and } \\
\text { MEME }\end{array}$ & $\begin{array}{l}\text { Huber and Bulyk, } \\
2006\end{array}$ \\
\hline PAZAR & http://sourceforge.net/projects/pazar & $\begin{array}{l}\text { A framework to allow multiple } \\
\text { boutique databases to function } \\
\text { independently within a larger } \\
\text { system; a public repository for } \\
\text { regulatory data }\end{array}$ & $\begin{array}{l}\text { Wasserman et al., } \\
\text { unpublished }\end{array}$ \\
\hline RSAT & http://rsat.ulb.ac.be/rsat/ & $\begin{array}{l}\text { Series of modular computer } \\
\text { programs to detect regulatory } \\
\text { signals }\end{array}$ & van Helden, 2003 \\
\hline TRANSFAC & $\begin{array}{l}\text { http://www.gene-regulation.com/ } \\
\text { pub/databases.html }\end{array}$ & $\begin{array}{c}\text { Database of eukaryotic } \\
\text { transcription factors and their } \\
\text { binding sites }\end{array}$ & Knuppel et al., 1994 \\
\hline Worm Enhancer & http://wormenhancer.org/Main & $\begin{array}{l}\text { Find clusters of binding sites in } \\
\text { the genome. }\end{array}$ & $\begin{array}{l}\text { Markstein, Markstein, } \\
\text { Levine, unpublished }\end{array}$ \\
\hline
\end{tabular}

\section{Temporal control during organogenesis}

Patterning the pharyngeal primordium depends on successive programs of gene expression. How is this achieved? One input is PHA-4 itself (see Figure 6). Promoter analyses suggest that PHA-4 directly regulates many genes expressed in the pharynx, including genes active both early and late, (Gaudet and Mango, 2002; Gaudet et al., 2004; Kalb et al., 1998; Kuchenthal et al., 2001; Smith and Mango, 2006; Vilimas et al., 2004). The affinity of PHA-4 for its binding sites contributes to the timing of target gene activation (Gaudet and Mango, 2002; Gaudet et al., 2004). Mutations that alter the affinity of PHA-4 binding sites higher or lower shift the onset of target gene expression earlier or later, respectively. These temporal shifts occur in the context of the promoter, and are not an absolute predictor of transcriptional activation of target genes. Moreover, they depend on recruitment of the histone variant HTZ-1 for a subset of pharyngeal promoters (Updike and Mango, 2006). Thus, PHA-4 may function as a competence factor (Zaret, 2002) that modulates chromatin to prime a promoter for activation.

A second means for temporal control is feed-forward regulation (see Figure 6). For example, PHA-4 activates ceh-22/Nkx2.5 and both PHA-4 and CEH-22 activate myo-2, which encodes a myosin heavy chain expressed in terminally-differentiating pharyngeal muscles (Gaudet and Mango, 2002; Kalb et al., 1998; Mango et al., 1994; Okkema and Fire, 1994; Okkema et al., 1997). The involvement of CEH-22 in myo-2 transcription helps explain why the myo-2 promoter fires late in embryogenesis, even though it possesses a high affinity PHA-4 binding site. However, CEH-22 is expressed by mid-embryogenesis (bean stage), whereas myo-2 transcription initiates later (two-fold stage), suggesting additional inputs are involved.

Combinatorial regulation is the third means to control timing (see Figure 6). A single PHA-4 binding site, similar to what exists in most promoters, is not sufficient to activate expression (Gaudet et al., 2004). Multiple PHA-4 binding sites can activate transcription throughout the pharynx, but this configuration is rarely seen in natural promoters (Gaudet et al., 2004). Bioinformatic searches for sequences over-represented in pharyngeal gene promoters led to the discovery of two motifs associated with early-expressed pharyngeal genes and two associated with late-expressed pharyngeal genes (Gaudet et al., 2004). These early and late cis elements were tested for biological function in two ways. One was necessity: were the sequences required for expression of natural 
pharyngeal promoters? Mutation of the candidate sites revealed whether natural promoters required the sequences for normal expression. The second was sufficiency - could three copies of a candidate element introduced upstream of the pes-10 basal promoter activate GFP transcription? For these kinds of assays to succeed, GFP reporters were introduced into worms without vector sequences, which can contain cryptic pharyngeal enhancers (Hope, 1991; Young and Hope, 1993). In addition, low concentrations of reporter DNA ( $\leq 2 \mathrm{ng} / \mathrm{ul})$ were used, as were more likely to recapitulate endogenous expression (Gaudet and Mango, 2002; Gaudet et al., 2004). In Table 2 I list algorithms and databases that may be helpful for identifying transcription factor binding sites within groups of genes.

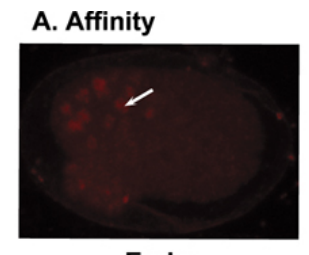

Early

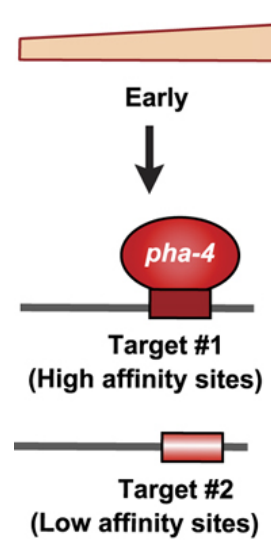

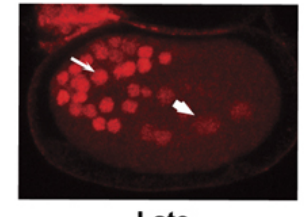

Late

PHA-4 Concentration

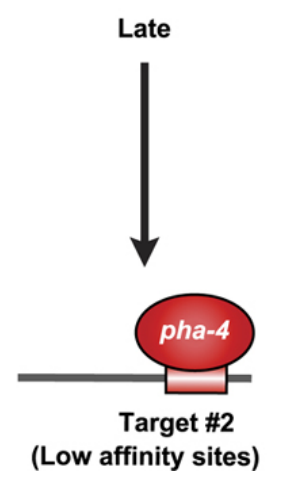

B. Feed Forward

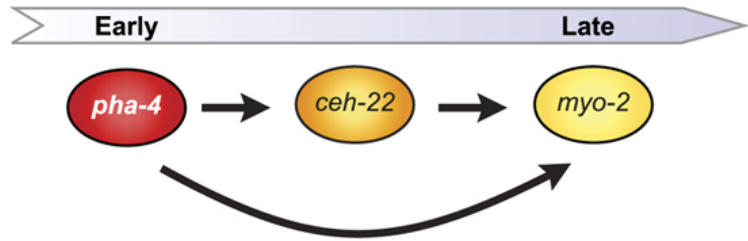

C. Combinatorial

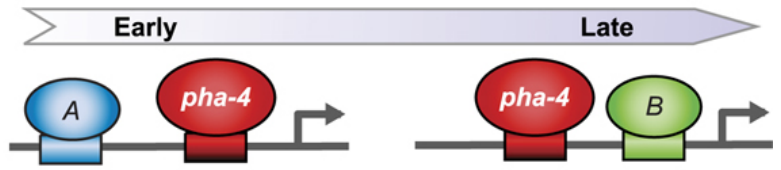

Figure 6. Strategies for temporal control. A. As embryogenesis proceeds, PHA-4 protein accumulates. Affinity of PHA-4 protein for its DNA binding site contributes to early (high affinity) vs. late (lower affinity) onset of expression. B. Feed-forward regulation contributes to late onset expression of target genes, including those with high affinity PHA-4-binding (e.g., myo-2). C. Pharyngeal genes are regulated by additional factors (A and B) in addition to PHA-4. These can include both activators and repressors.

\section{Cell-type regulation}

The mechanisms that establish individual pharyngeal cell types are best understood for pharyngeal muscles. The early events, during gastrulation, rely on PHA-4 and the Tbox genes described above. Less is known about later differentiation of the pharyngeal muscles. A hallmark of pharyngeal muscle differentiation is transcription of myo-2/myosin exclusively within pharyngeal muscles. The myo-2 promoter has been analyzed extensively (Ao et al., 2004; Gaudet and Mango, 2002; Okkema and Fire, 1994; Okkema et al., 1993). Two cis-regulatory elements, B and $\mathrm{C}$, are required for full activity of myo-2. The B subelement binds CEH-22, which is expressed in a subset of pharyngeal muscles. The C subelement binds PHA-4 and PEB-1, a FLYWCH zinc finger factor related to Mod(mdg4), which is involved in insulator function in Drosophila (Beaster-Jones and Okkema, 2004; Kalb et al., 2002; Thatcher et al., 2001). The nuclear hormone receptor DAF-12 also activates myo-2 and mediates the modulation of myo-2 in response to nutrition (Ao et al., 2004). Surprisingly, inactivation of the binding sites of each of these factors does not block myo-2 expression. Conversely, Mutation of pha-4 binding sites leads to a delay in myo-2 activation (Gaudet and Mango, 2002). ceh-22 is required for isolated B element activity but endogenous myo-2 is still active in ceh-22 mutants (Okkema et al., 1997). peb-1 mutants die because they cannot shed their cuticle during molting, which may reflect feeding defects and/or additional functions of peb-l (Fernandez et al., 2004). Nevertheless, myo-2 expression appears normal. daf-12 mutations lower myo-2 reporter expression but do not obliterate it (Ao et al., 2004). Thus, the organism uses multiple inputs to assure robust expression of pharyngeal myosin and no one factor is essential.

Expression and specification of other pharyngeal cell types is less well understood. The Six family homeodomain protein $u n c-39$ is expressed in the pharyngeal arcade cells. Mutants have a misshapen pharynx and sometimes arrest with a Pun (Pharynx UNattached) pharynx, however it is unclear if this phenotype represents loss of arcade cell identity or defective morphogenesis (Yanowitz et al., 2004). 
Additional genomic-scale searches of pharyngeal promoters have identified potential new regulators (Ao et al., 2004; GuhaThakurta et al., 2004). Ao and colleagues used microarray analysis and TopoMap clustering to identify genes expressed in different pharyngeal cell types (Ao et al., 2004). These cohorts of genes were then used to search for new cis-regulatory elements that dictate expression in muscle or epithelia. Conversely, using a yeast one-hybrid approach, Deplancke and colleagues discovered factors that bound digestive tract promoters (Deplancke et al., 2006). The authors surveyed 112 gut promoters or regulatory elements for transcription factor binding using a yeast one-hybrid assay and discovered 283 interactions involving 72 promoters and 117 interacting factors (Deplancke et al., 2006). Most factors interacted with a small number of genes and conversely most genes had multiple factors binding, an average of four. The factors discovered in this screen are presumably those that can bind as monomers or homomers in yeast, suggesting this is just the tip of the iceberg.

\section{Transcriptional strategies for organogenesis}

It is intriguing to compare the transcriptional strategies of cell fate specification and differentiation for the pharynx vs. the midgut, two very different organs. Pharynx development depends on PHA-4, which functions at multiple stages of development and in all pharyngeal cell types. To achieve diversity, pharyngeal promoters are regulated by a combinatorial mechanism. This strategy depends on transcription factors that are weak activators. For example, when expressed ectopically, PHA-4 can change the fate of only a subset of embryonic cells to pharynx (Horner et al., 1998). When introduced into yeast, PHA-4 functions poorly as a transcriptional activator in one-hybrid assays (Kalb et al., 2002). The configuration of pharyngeal promoters also dampens the effect of any one factor. Pharyngeal promoters typically contain multiple cis-regulatory sites (Deplancke et al., 2006; Gaudet et al., 2004), but individual sites are often suboptimal for binding a given transcription factor and are present in only 1-2 copies (Gaudet and Mango, 2002). Thus, the input from any one transcription factor is minor, and promoter firing depends on multiple weak inputs at a promoter.

The midgut, on the other hand, is a simple organ, composed of one cell type that derives from a single precursor, the E blastomere. This simplicity is mirrored at the transcriptional level. The midgut depends on tiers of GATA transcription factors that function for only 1-2 cell divisions and elicit a more homogeneous transcriptional response (Maduro et al., 2005a). As a consequence, these regulatory GATA factors are more potent activators and probably do not rely heavily on combinatorial mechanisms to activate their target genes. For example, widespread expression of one of these GATA factors, end-1, can convert the entire embryo into midgut (Zhu et al., 1998) and another GATA factor, elt-2, is a potent activator in yeast one-hybrid assays (Kalb et al., 2002). Surprisingly, these tiers of GATA factors are genetically redundant, and their individual contributions are just beginning to be understood (Maduro et al., 2006). Analysis of MED-1/2 target genes reveals a surprisingly simple code: two copies of the invariant sequence RRRAGTATAC in a 100bp stretch and within $2 \mathrm{~kb}$ of the ATG start codon. These rules predicted 21 MED target genes of which at least 12/15 behaved as expected for a MED target (Broitman-Maduro et al., 2005). Thus, the simplicity of the intestine is mirrored in a simpler transcriptional strategy: more potent transcription factors, less binding sequence heterogeneity and a simpler promoter architecture. It will be interesting, as more target genes emerge, to determine if these distinctions continue to hold true.

\section{Morphogenesis}

By mid-embryogenesis, gastrulation is finished, cell division is almost complete, and the pharyngeal primordium is visible as a ball of cells bordering the nascent midgut in the interior of the embryo (Portereiko and Mango, 2001; Sulston et al., 1983). The pharyngeal cells are attached to each other and to the midgut by adherens junctions (Leung et al., 1999), but are not yet connected to the buccal cavity. Over the next sixty minutes, the pharyngeal cells shift their position and organization to form a linear tube that links the digestive tract to the exterior (Portereiko and Mango, 2001). The initial event of morphogenesis is reorganization of the pharyngeal primordium. Pharyngeal epithelial cells reorient their apicobasal polarity from rostrocaudal to dorsoventral relative to the embryonic axes (see Figure 7A to B). This rearrangement alters the morphology of the pharynx from a cyst, with the apical surfaces located internally, to a short tube that extends from the midgut to the anterior edge of the pharyngeal primordium. This movement aligns the pharyngeal epithelial cells with the arcade cells. Next, the arcade cells form adherens junctions that link the pharynx and epidermis, to form a continuous epithelium (see Figure 7B to C). This event mechanically couples the buccal cavity to the pharynx and anterior epidermis. During the third stage of pharyngeal extension, cells of the pharynx, buccal cavity and epidermis appear to undergo a local contraction that pulls them tightly together (see Figure $7 \mathrm{C}$ to $\mathrm{D}$ ). The remainder of the pharynx is presumably dragged forward by virtue of its attachment to the anterior pharynx. Once connected the pharynx undergoes additional morphogenesis, to produce the bi-lobed structure of the mature pharynx. 

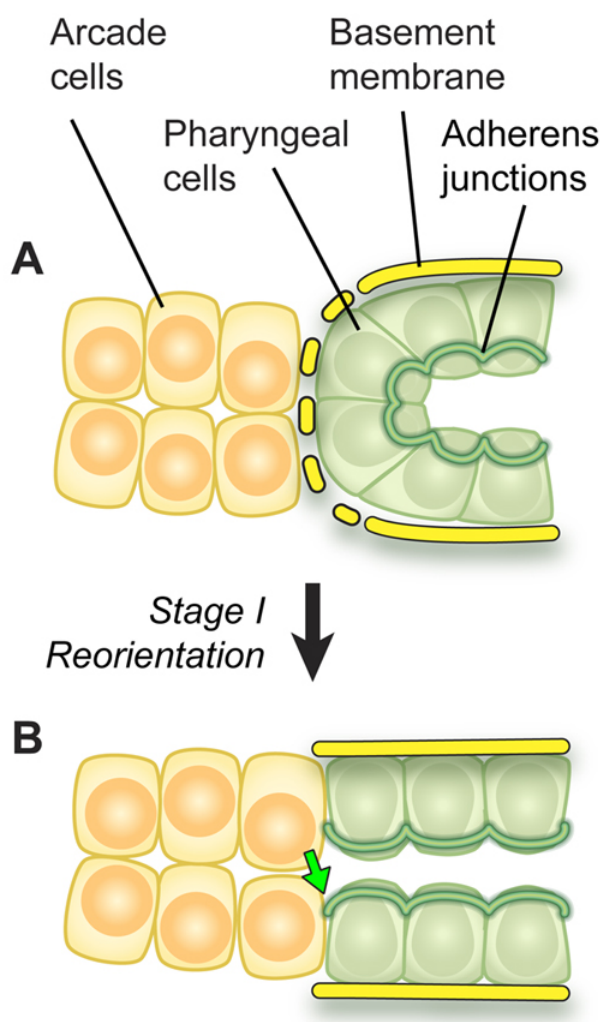

\section{Stage II
Epithelialization}

C
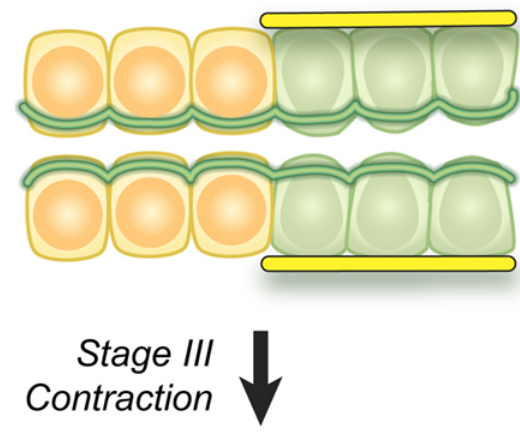

D
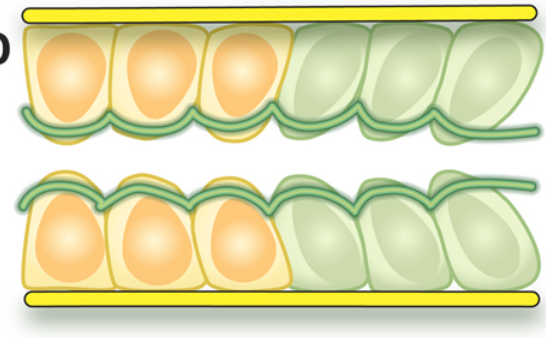
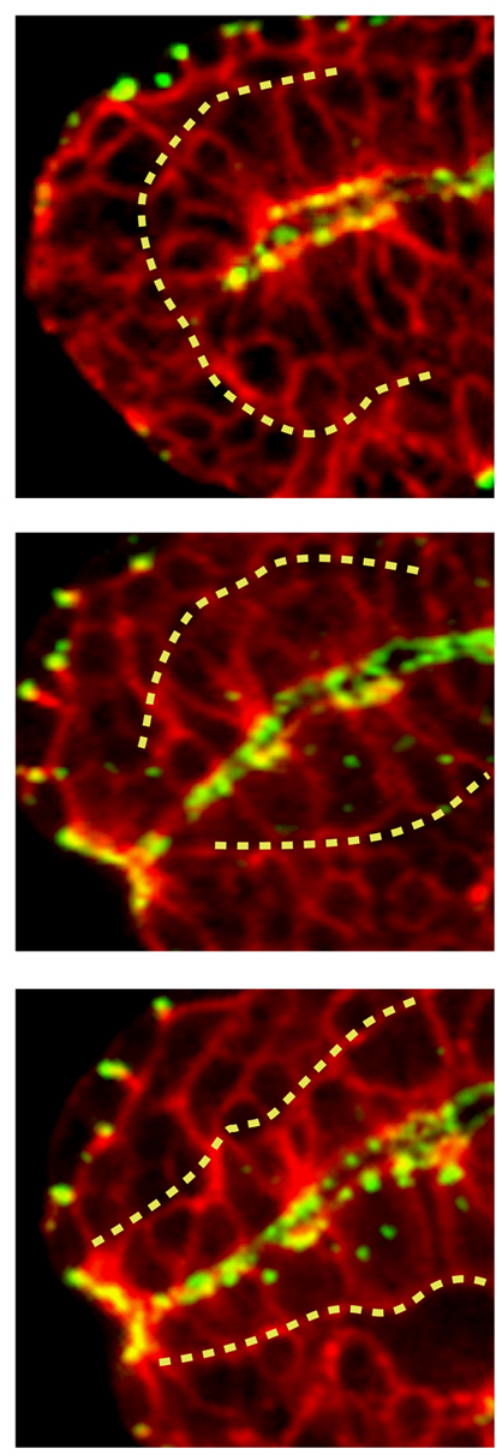

Figure 7. Pharyngeal morphogenesis. Left panels depict stages of Reorientation (A to B, Stage 1), Epithelialization (B to C, Stage 2) and Contraction (C to D, Stage 3). Yellow cells denote arcade cells, which are initially mesenchymal (A, B), but later become epithelialized (C, D). Green cells represent cells in the pharyngeal primordium. Right panels show midstage embryos stained for cell periphery (red, $\alpha \mathrm{UNC}-70$ ) and adherens junctions (green, MH27), merge is yellow. The basement membrane surrounding the pharynx is denoted by a dotted yellow line in both sets of panels. 
The C. elegans pharynx: a model for organogenesis

Table 3. Genes involved in pharyngeal morphogenesis. Genes that lead to a morphogenesis defect when mutaM/Z: maternal or zygotic contribution, phx: pharyngeal, Ref: references, ?: unknown.

\begin{tabular}{|c|c|c|c|c|c|c|}
\hline Gene & Homology & $\mathbf{M} / \mathbf{Z}$ & $\begin{array}{c}\text { Cellular } \\
\text { expression }\end{array}$ & Localization & Function & References \\
\hline cyk-4 & $\begin{array}{l}\text { MgcRacGAP } \\
\text { RhoGAP }\end{array}$ & $\mathrm{M}, \mathrm{Z}$ & Broadly & $?$ & $\begin{array}{l}\text { Apicobasal } \\
\text { polarity }\end{array}$ & $\begin{array}{l}\text { Portereiko et al., 2004; } \\
\text { Jenkins et al., } 2006\end{array}$ \\
\hline$z e n-4$ & $\begin{array}{l}\text { MKLP1 } \\
\text { kinesin }\end{array}$ & $\mathrm{M}, \mathrm{Z}$ & Broadly & $?$ & $\begin{array}{l}\text { Apicobasal } \\
\text { polarity }\end{array}$ & Portereiko et al., 2004 \\
\hline ast-1 & ETS & $\mathrm{Z}$ & Head & $\mathrm{N} / \mathrm{C}$ & Pha attachment & Schmid et al., 2006 \\
\hline crp-1 & $c d c-42$ related & $\mathrm{Z}$ & $\begin{array}{c}\text { Muscles and } \\
\text { non-phx epithelia }\end{array}$ & $\begin{array}{c}\text { Endosomes, } \\
\text { trans-Golgi network }\end{array}$ & Apical trafficking & Jenna et al., 2005 \\
\hline let-413 & scribble & $\mathrm{Z}$ & Epithelia & Basolateral & $\begin{array}{l}\text { Confinement of } \\
\text { CeAJ }\end{array}$ & $\begin{array}{l}\text { Legouis et al., 2000; } \\
\text { McMahon et al., 2001 }\end{array}$ \\
\hline die-1 & Zinc finger TF & $\mathrm{Z}$ & Epithelia & Nuclear & Pha attachment & Heid et al., 2001 \\
\hline eff-1 & Novel & $\mathrm{Z}$ & $\begin{array}{l}\text { Muscles, non-phx } \\
\text { fusing epithelia }\end{array}$ & Contact points & Epithelial fusion & $\begin{array}{l}\text { Mohler et al., 2002; } \\
\text { Shemer et al., } 2004\end{array}$ \\
\hline $\begin{array}{c}\text { elt-5/ } \\
\text { egl-18 }\end{array}$ & GATA TF & $\mathrm{Z}$ & $\begin{array}{l}\text { Non-pha } \\
\text { epidermis, } \\
\text { neurons }\end{array}$ & Nuclear & Pha attachment & $\begin{array}{l}\text { Koh et al., 2002; Koh } \\
\text { and Rothman, 2001 }\end{array}$ \\
\hline$f b l-1$ & Fibulin & $\mathrm{Z}$ & Non-phx & $\begin{array}{l}\text { Basement } \\
\text { membrane }\end{array}$ & Pha morphology & Muriel et al., 2005 \\
\hline ham-2 & Zinc finger & $\mathrm{Z}$ & Embryo & Nuclear & Pha attachment & Baum et al., 1999 \\
\hline in $x-3$ & Innexin & $\mathrm{Z}$ & Broadly, epithelia & Basal surface & $\begin{array}{l}\text { Pha attachment } \\
\text { pha morphology }\end{array}$ & Starich et al., 2003 \\
\hline pha-1 & DUF1114 & $\mathrm{Z}$ & Ubiquitous & Cytoplasmic & $\begin{array}{l}\text { Pha attachment } \\
\text { pha } \\
\text { differentiation }\end{array}$ & $\begin{array}{l}\text { Fay et al., 2004; } \\
\text { Granato et al., 1994; } \\
\text { Schnabel and } \\
\text { Schnabel, } 1990\end{array}$ \\
\hline$u b c-18$ & $\begin{array}{c}\text { Ubiquitin conj } \\
\text { ez }\end{array}$ & $?$ & $?$ & $?$ & Pha attachment & Fay et al., 2003 \\
\hline ari-1 & $\begin{array}{c}\text { Ariadne RING } \\
\text { finger }\end{array}$ & $?$ & Broadly & $?$ & Pha attachment & Qiu and Fay, 2006 \\
\hline lin-35 & $\mathrm{Rb}$ repressor & $?$ & Broadly & Nuclear & Pha attachment & Fay et al., 2003 \\
\hline sma-1 & $\beta \mathrm{H}$-spectrin & $\mathrm{Z}$ & Epithelia & Apical & Pha elongation & McKeown et al., 1998 \\
\hline$s p c-1$ & $\alpha$-spectrin & $\mathrm{Z}$ & Epithelia & Apical & Pha elongation & $\begin{array}{l}\text { Norman and } \\
\text { Moerman, } 2002\end{array}$ \\
\hline
\end{tabular}

Many factors affect pharynx morphogenesis, based on loss-of-function phenotypes, but it is unclear if these phenotypes reflect cell fate, differentiation or morphogenesis. Deletion of the ETS homologue ast- 1 leads to pharynx unattached (Pun) larvae that cannot feed (Schmid et al., 2006). By time-lapse videomicroscopy, pharyngeal development proceeds normally to the 1.5 fold stage when pharyngeal cells fail to attach to the buccal cavity. AST-1::GFP is expressed in the head, including a few unidentified pharyngeal cells. It is unclear whether the pharyngeal defects reflect a function for AST-1 in the pharynx or in surrounding head cells. 

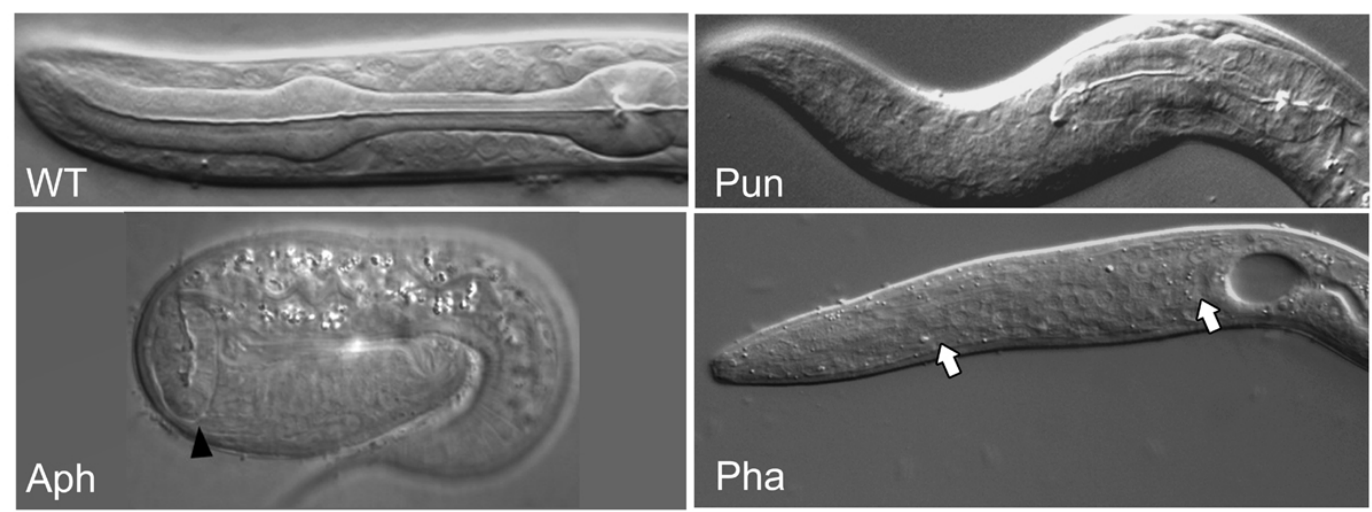

Figure 8. Pharyngeal phenotypes. Examples of pharyngeal phenotypes: wild type WT, pharynx unattached Pun (zen-4), anterior pharynx absent Aph (aph-1) and pharynx absent Pha (pha-4). Note the full size but unattached Pun pharynx compared to the smaller than normal Aph pharynx (arrowhead). In Pha animals, no pharynx is observed (arrows). Aph animal kindly reproduced from Goutte et al. (2002).

The pha-2 homeobox is important for isthmus morphogenesis (Morck et al., 2004). Animals lacking pha-2 have an abnormally thick pharyngeal isthmus, cells of the anterior bulb appear to mix with those of the isthmus, and CEH-22/Nkx2.5 is expressed inappropriately in pm5, which forms the isthmus (Morck et al., 2004). These data suggest that pha-2 is required to distinguish pm5 fate or morphology, distinct from the other pharyngeal muscles.

The ceh-43/distal-less homolog is not obviously expressed in the pharynx but loss of ceh-43 activity by RNAi leads to a detached pharynx, possibly because of problems with the epidermal epithelium (Aspock and Burglin, 2001). Similarly, loss of the GATA factor elt-5 produces animals with Pun pharynges, likely due to epidermal defects (Koh et al., 2002).

The eya-1 locus is homologous to eyes absent and carries two HAD domains (Furuya et al., 2005). In other animals, eyes absent is a phosphatase co-factor for the sine oculis transcription factor and part of the eye regulatory circuit (Rebay et al., 2005). In worms, eya-1 mutants arrest at the L1 or L2 stage with a thin pharynx and reduced pumping rates (Furuya et al., 2005). The pharyngeal bulb can be misshapen and the lumen stuffed with bacteria, suggesting a feeding defect. eya-1 is partially redundant with vab-3/pax-6 suggesting that the regulatory circuit that controls eye development in other animals may have adopted a new function for anterior development in C. elegans, which lacks eyes (Furuya et al., 2005).

die-1 encodes a zinc finger transcription factor expressed in many epithelia including the pharynx (Heid et al., 2001). die-1 mutants can be detached from either the intestine or from the buccal cavity (Heid et al., 2001). DIE-1 is expressed in the pharynx, although the precise cells are unknown. DIE-1 binds multiple genes by yeast one-hybrid analysis, including genes many genes implicated in transcription (Deplancke et al., 2006).

sma-1 encodes $\beta \mathrm{H}$ (heavy)-spectrin, which is essential for the elongated form of the pharynx (McKeown et al., 1998). Mutants are viable but the procorpus and isthmus fail to elongate. Some of these defects may reflect the lack of body elongation rather than internal to the pharynx itself. Association of SMA-1 to apical surfaces of epithelia depends on $\alpha$-spectrin (Norman and Moerman, 2002).

The transcriptional repressor lin-35/Rb and the ubiquitin conjugating enzyme $u b c-18$ are required redundantly for the first stage of pharyngeal morphogenesis, Reorientation (Fay et al., 2003). Inactivation of both genes leads to arrested Pun animals (Fay et al., 2003). Similarly, inactivation of pha-1 and either $u b c-18$ or ari-1/Ariadne leads to an unattached pharynx phenotype (Fay et al., 2004; Qiu and Fay, 2006). One model to explain these complicated interactions is that over-expression of a factor " $\mathrm{X}$ " leads to a Pun phenotype. Transcriptional repression (e.g., lin-35) and protein degradation ( $u b c-18$ or ari-1) normally keep X in check. However, when both are inactivated, X excess inhibits pharyngeal morphogenesis. It is unclear what role the pha- 1 plays in this process. pha- 1 encodes a DUF1114 factor expressed in the cytoplasm (Fay et al., 2004). 


\section{Epithelium formation-the pharyngeal arcade cells}

C. elegans epithelia resemble those of other organisms, with apical and basolateral domains (Knust and Bossinger, 2002). LET-413/scribble is localized to the basolateral domain, where it restricts the spread of components of adherens junction and the apical domain (Koppen et al., 2001; Legouis et al., 2000; McMahon et al., 2001), while the PAR-3/PAR-6 complex is confined to the apical domain (Leung et al., 1999). A single junction, the CeAJ, separates the apical and basolateral domains and has features of both adherens and tight junctions. For example, the CeAJ contains proteins that mediate adhesion such as HMR-1/cadherin, HMP-1/alpha-catenin, HMP-2/beta-catenin and VAB-9/claudin (Costa et al., 1998; Pettitt et al., 1996; Simske and Hardin, 2001). Located slightly more basally but still within the CeAJ are DLG-1/discs large and the coiled-coil protein AJM-1 (Bossinger et al., 2001; Koppen et al., 2001). The Fat subfamily cadherin $c d h-3$ is expressed in the pharynx and would be predicted to localize to CeAJs (Pettitt et al., 1996).

What factors are required to build the pharynx epithelium? Surprisingly, many proteins implicated in the formation or maintenance of epithelia in other animals are apparently not essential in the C. elegans digestive tract. For example, homologues of Crumbs, cadherins, discs-large, ZO- $1, \alpha$ - or $\beta$-integrins do not give rise to obvious pharyngeal defects after being inactivated (Baum and Garriga, 1997; Costa et al., 1998; Drubin and Nelson, 1996; Pettitt et al., 1996; Williams and Waterston, 1994). These data suggest $C$. elegans may rely on additional molecules to establish epithelia. Intriguingly, studies with other organisms suggest alternative routes for epithelium formation exist in these animals also (Baas et al., 2004; Bilder et al., 2003; Harris and Peifer, 2004).

The kinesin-like protein zen-4/MKLP and its partner $c y k-4 /$ RhoGAP are required to polarize the arcade cells (Portereiko et al., 2004). Apical and adherens junction proteins fail to accumulate at the cell surface of arcade cells from zen-4 mutants, even though these proteins are synthesized in the cell. Thus, zen-4 and cyk-4 appear important to target polarity proteins to the apical surface and CeAJ during polarization. Recent studies suggest that CYK-4 modulates cell polarity in other contexts by controlling RhoA activity and the contractile actomyosin cytoskeleton (Jenkins et al., 2006); perhaps this regulatory pathway will hold true for the pharyngeal epithelium as well.

LET-413, which contains a PDZ motif and leucine-rich repeats similar to Drosophila scribble, is localized to basolateral membranes of all epithelial cell types, including the pharynx (Chanal et al., 1997; Legouis et al., 2000). In epidermal cells lacking let-413/scribble, apical proteins such as PKC-3 are mislocalized, and CeAJ-associated proteins such as DLG-1 and AJM-1 remain along the lateral surface rather than becoming condensed into the junctional region as in wildtype (McMahon et al., 2001). Thus, LET-413 may function after ZEN-4 and CYK-4 to control adherens junction maturation and positioning.

\section{Is the pharynx a heart?}

There has been debate about a possible evolutionary relationship between the $C$. elegans pharynx and the vertebrate heart. Three observations suggest that the pharynx may be orthologous to the vertebrate heart. First, both the pharynx and heart are tubes that move material along their lumens using binucleate muscles (Albertson and Thomson, 1976; Kellerman et al., 1992). Both organs pump continuously, for the life of the organism. Second, both organs rely on similar electrical circuitry to control pumping. Contractions are synchronized by gap junctions that couple adjacent muscle cells, and contractions can continue in the absence of neuronal input (Avery and Horvitz, 1989; Bernstein and Morley, 2006; Starich et al., 1996; Starich et al., 2003). Contraction speed can be modulated by neurotransmitters that couple to GPCRs, including acetylcholine and serotonin (Hobson et al., 2003; Penela et al., 2006; Steger and Avery, 2004). The pharynx and heart rely on some similar types of channels such as the LQT potassium channels and L-type voltage-gated calcium channels (Avery and Horvitz, 1989; Raizen and Avery, 1994; Salkoff et al., 2005). Third, both organs rely on NKX transcription factors for their genesis: ceh-22 for the pharynx and $N k x 2.5$ for the zebrafish heart (Chen and Fishman, 1996; Okkema and Fire, 1994; Okkema et al., 1997). Moreover, Nkx2.5 can activate the CEH-22 target gene myo-2 when expressed in C. elegans body wall muscles, and Nkx2.5 can rescue ceh-22 mutants when expressed under control of the ceh-22 promoter (Haun et al., 1998).

Despite these similarities, three observations suggest that parallels between the pharynx and heart may represent convergent evolution rather than true homology. First, while the heart is a mesodermal organ, the pharynx appears to be ectodermal. Topologically, the pharynx is connected to the epidermis and, like the epidermis, is lined with cuticle (Albertson and Thomson, 1976). Pharyngeal muscle is myoepithelial, displaying apical domains separated by adherens junctions from the basolateral surfaces, which contact a basal lamina (Albertson and Thomson, 1976; Portereiko and Mango, 2001). In pha-4 mutant embryos, at least a portion of pharyngeal cells are 
transformed into ectodermal cell types, but not into mesodermal cell types (Horner et al., 1998; Kiefer et al., 2006). Second, the involvement of Nkx2.5 proteins for pharyngeal development may be misleading. In other organisms, $\mathrm{Nkx} 2.5$ factors are required for visceral muscle development as well as heart formation (e.g., tinman in Drosophila (Bodmer, 1993). This observation may explain why $N k x 2.5$, which is normally restricted to myocardiocytes in zebrafish, can nevertheless rescue visceral muscle development in Drosophila Nkx/tinman mutants (Park et al., 1998). Third, aspects of the electrical conductivity are different between the pharynx and heart. C. elegans lacks the voltage-gated sodium channel that typically initiates the action potential with a fast sodium spike in the heart (L. Avery, pers. comm.). The pharynx is excited by motor neurons via nicotinic receptors, similar to mammalian skeletal muscle (McKay et al., 2004; Raizen et al., 1995; Towers et al., 2005). The potassium channels that end the action potential are only distantly related between pharyngeal exp-2 and cardiac hERG (Davis et al., 1999; Shtonda and Avery, 2005). These differences suggest that similarities between the two organs may represent convergent evolution between two muscular pumps faced with similar biological roles.

\section{Conclusion}

To form the pharynx, C. elegans faces developmental challenges that are similar to those of more complex animals and uses conserved molecular pathways to meet those challenges. With the ability to visualize individual cells during organogenesis and the development of powerful tools (genomics, forward and reverse genetics, molecular biology), scientists have begun to discover the genes required for cell fate specification and morphogenesis. Our challenge for the future is to uncover the function of these genes and to dissect the regulatory networks that drive these processes.

\section{Acknowledgements}

Many thanks to Alex Schier for comments on the manuscript, Leon Avery for discussions regarding pharynx neurobiology and evolution, David Hall and Zeynep Altun for Figure 2, Diana Lim for the illustrations, Jim Priess for the Aph panel in Figure 8 and all my lab, current and past, for discussions on pharyngeal development. S.E.M. is supported by R01 DK070184 and R01 GM056264 from the NIH. She receives institutional support from the Huntsman Cancer Institute and Department of Oncological Sciences.

\section{References}

Ahnn, J., and Fire, A. (1994). A screen for genetic loci required for body-wall muscle development during embryogenesis in Caenorhabditis elegans. Genetics 137, 483-498. Abstract

Albertson, D.G., and Thomson, J.N. (1976). The pharynx of Caenorhabditis elegans. Philos. Trans. R. Soc. Lond., B, Biol. Sci. 275, 299-325. Abstract

Alder, M.N., Dames, S., Gaudet, J., and Mango, S.E. (2003). Gene silencing in Caenorhabditis elegans by transitive RNA interference. RNA 9, 25-32. Abstract Article

Andachi, Y. (2004). Caenorhabditis elegans T-box genes $t b x-9$ and $t b x-8$ are required for formation of hypodermis and body-wall muscle in embryogenesis. Genes Cells 9, 331-344. Abstract Article

Ao, W., Gaudet, J., Kent, W.J., Muttumu, S., and Mango, S.E. (2004). Environmentally induced foregut remodeling by PHA-4/FoxA and DAF-12/NHR. Science 305, 1743-1746. Abstract Article

Aspock, G., and Burglin, T.R. (2001). The Caenorhabditis elegans distal-less ortholog ceh-43 is required for development of the anterior hypodermis. Dev. Dyn. 222, 403-409. Abstract Article

Aspock, G., Ruvkun, G., and Burglin, T.R. (2003). The Caenorhabditis elegans ems class homeobox gene ceh-2 is required for M3 pharynx motorneuron function. Development 130, 3369-3378. Abstract Article

Avery, L. (1993). The genetics of feeding in Caenorhabditis elegans. Genetics 133, 897-917. Abstract

Avery, L., and Horvitz, H.R. (1989). Pharyngeal pumping continues after laser killing of the pharyngeal nervous system of C. elegans. Neuron 3, 473-485. Abstract Article 
Azzaria, M., Goszczynski, B., Chung, M.A., Kalb, J.M., and McGhee, J.D. (1996). A fork head/HNF-3 homolog expressed in the pharynx and intestine of the Caenorhabditis elegans embryo. Dev. Biol. 178, 289- 303. Abstract Article

Baas, A.F., Kuipers, J., van der Wel, N.N., Batlle, E., Koerten, H.K., Peters, P.J., and Clevers, H.C. (2004). Complete polarization of single intestinal epithelial cells upon activation of LKB1 by STRAD. Cell 116, 457-466. Abstract Article

Bailey, T.L., and Elkan, C. (1994). Fitting a mixture model by expectation maximization to discover motifs in biopolymers. Proc. Int. Conf. Intell. Syst. Mol. Biol. 2, 28-36. Abstract

Bailey, T.L., and Gribskov, M. (1998). Combining evidence using p-values: application to sequence homology searches. Bioinformatics 14, 48-54. Abstract Article

Baugh, L.R., Hill, A.A., Slonim, D.K., Brown, E.L., and Hunter, C.P. (2003). Composition and dynamics of the Caenorhabditis elegans early embryonic transcriptome. Development 130, 889-900. Abstract Article

Baum, P.D., and Garriga, G. (1997). Neuronal migrations and axon fasciculation are disrupted in ina-1 integrin mutants. Neuron 19, 51-62. Abstract Article

Baum, P.D., Guenther, C., Frank, C.A., Pham, B.V., and Garriga, G. (1999). The Caenorhabditis elegans gene ham-2 links Hox patterning to migration of the HSN motor neuron. Genes Dev. 13, 472-483. Abstract

Beaster-Jones, L., and Okkema, P.G. (2004). DNA binding and in vivo function of $C$. elegans PEB-1 require a conserved FLYWCH motif. J. Mol. Biol. 339, 695-706. Abstract Article

Bernstein, S.A., and Morley, G.E. (2006). Gap junctions and propagation of the cardiac action potential. Adv. Cardiol. 42, 71-85. Abstract Article

Bigelow, H.R., Wenick, A.S., Wong, A., and Hobert, O. (2004). CisOrtho: a program pipeline for genome-wide identification of transcription factor target genes using phylogenetic footprinting. BMC Bioinformatics 5, 27. Abstract Article

Bilder, D., Schober, M., and Perrimon, N. (2003). Integrated activity of PDZ protein complexes regulates epithelial polarity. Nat. Cell Biol. 5, 53-58. Abstract Article

Bodmer, R. (1993). The gene tinman is required for specification of the heart and visceral muscles in Drosophila. Development 118, 719-729. Abstract

Bossinger, O., Klebes, A., Segbert, C., Theres, C., and Knust, E. (2001). Zonula adherens formation in Caenorhabditis elegans requires $d l g-1$, the homologue of the Drosophila gene discs large. Dev. Biol. 230, $29-42$. Abstract Article

Bowerman, B., Draper, B.W., Mello, C.C., and Priess, J.F. (1993). The maternal gene $s k n-1$ encodes a protein that is distributed unequally in early C. elegans embryos. Cell 74, 443-452. Abstract Article

Bowerman, B., Eaton, B.A., and Priess, J.R. (1992). skn-1, a maternally expressed gene required to specify the fate of ventral blastomeres in the early C. elegans embryo. Cell 68, 1061-1075. Abstract Article

Broitman-Maduro, G., Lin, K.T., Hung, W.W., and Maduro, M.F. (2006). Specification of the C. elegans MS blastomere by the T-box factor TBX-35. Development 133, 3097-3106. Abstract Article

Broitman-Maduro, G., Maduro, M.F., and Rothman, J.H. (2005). The noncanonical binding site of the MED-1 GATA factor defines differentially regulated target genes in the C. elegans mesendoderm. Dev. Cell 8, 427-433. Abstract Article

Burglin, T.R., and Aspock, G. (1999). Exon duplication from a fork head to a homeodomain protein. Dev. Genes Evol. 209, 629-633. Abstract Article 
Calvo, D., Victor, M., Gay, F., Sui, G., Luke, M.P., Dufourcq, P., Wen, G., Maduro, M., Rothman, J., and Shi, Y. (2001). A POP-1 repressor complex restricts inappropriate cell type-specific gene transcription during Caenorhabditis elegans embryogenesis. EMBO J. 20, 7197-7208. Abstract Article

Carlsson, P., and Mahlapuu, M. (2002). Forkhead transcription factors: key players in development and metabolism. Dev. Biol. 250, 1-23. Abstract Article

Chanal, P., and Labouesse, M. (1997). A screen for genetic loci required for hypodermal cell and glial-like cell development during Caenorhabditis elegans embryogenesis. Genetics 146, 207-226. Abstract

Chen, J.N., and Fishman, M.C. (1996). Zebrafish tinman homolog demarcates the heart field and initiates myocardial differentiation. Development 122, 3809-3816. Abstract

Christensen, S., Kodoyianni, V., Bosenberg, M., Friedman, L., and Kimble, J. (1996). lag-1, a gene required for lin-12 and glp-1 signaling in Caenorhabditis elegans, is homologous to human CBF1 and Drosophila $\mathrm{Su}(\mathrm{H})$. Development 122, 1373-1383. Abstract

Costa, M., Raich, W., Agbunag, C., Leung, B., Hardin, J., and Priess, J.R. (1998). A putative catenin-cadherin system mediates morphogenesis of the Caenorhabditis elegans embryo. J. Cell Biol. 141, 297-308. Abstract Article

Davis, M.W., Fleischhauer, R., Dent, J.A., Joho, R.H., and Avery, L. (1999). A mutation in the C. elegans EXP-2 potassium channel that alters feeding behavior. Science 286, 2501-2504. Abstract Article

Deplancke, B., Mukhopadhyay, A., Ao, W., Elewa, A.M., Grove, C.A., Martinez, N.J., Sequerra, R., Doucette-Stamm, L., Reece-Hoyes, J.S., Hope, I.A., et al. (2006). A Gene-Centered C. elegans Protein-DNA Interaction Network. Cell 125, 1193-1205. Abstract Article

Drubin, D.G., and Nelson, W.J. (1996). Origins of cell polarity. Cell 84, 335-344. Abstract Article

Evans, T.C., Crittenden, S.L., Kodoyianni, V., and Kimble, J. (1994). Translational control of maternal glp-1 mRNA establishes an asymmetry in the C. elegans embryo. Cell 77, 183-194. Abstract Article

Fay, D.S., Large, E., Han, M., and Darland, M. (2003). lin-35/Rb and $u b c-18$, an E2 ubiquitin-conjugating enzyme, function redundantly to control pharyngeal morphogenesis in C. elegans. Development 130, 3319-3330. Abstract Article

Fay, D.S., Qiu, X., Large, E., Smith, C.P., Mango, S., and Johanson, B.L. (2004). The coordinate regulation of pharyngeal development in C. elegans by lin-35/Rb, pha-1, and ubc-18. Dev. Biol. 271, 11-25. Abstract Article

Fernandez, A.P., Gibbons, J., and Okkema, P.G. (2004). C. elegans peb-1 mutants exhibit pleiotropic defects in molting, feeding, and morphology. Dev. Biol. 276, 352-366. Abstract Article

Frith, M.C., Li, M.C., and Weng, Z. (2003). Cluster-Buster: Finding dense clusters of motifs in DNA sequences. Nucleic Acids Res. 31, 3666-3668. Abstract Article

Fukushige, T., and Krause, M. (2005). The myogenic potency of HLH-1 reveals wide-spread developmental plasticity in early C. elegans embryos. Development 132, 1795-1805. Abstract Article

Furuya, M., Qadota, H., Chisholm, A.D., and Sugimoto, A. (2005). The C. elegans eyes absent ortholog EYA-1 is required for tissue differentiation and plays partially redundant roles with PAX-6. Dev. Biol. 286, 452-463. Abstract Article

Gaudet, J., and Mango, S.E. (2002). Regulation of organogenesis by the Caenorhabditis elegans FoxA protein PHA-4. Science 295, 821-825. Abstract Article

Gaudet, J., Muttumu, S., Horner, M., and Mango, S.E. (2004). Whole-genome analysis of temporal gene expression during foregut development. PLoS Biol. 2, e352. Abstract Article 
The C. elegans pharynx: a model for organogenesis

Gill, G. (2005). Something about SUMO inhibits transcription. Curr. Opin. Genet. Dev. 15, 536-541. Abstract Article

Good, K., Ciosk, R., Nance, J., Neves, A., Hill, R.J., and Priess, J.R. (2004). The T-box transcription factors TBX-37 and TBX-38 link GLP-1/Notch signaling to mesoderm induction in C. elegans embryos. Development 131, 1967-1978. Abstract Article

Goszczynski, B., and McGhee, J.D. (2005). Reevaluation of the role of the med-1 and med-2 genes in specifying the Caenorhabditis elegans endoderm. Genetics 171, 545-555. Abstract Article

Goutte, C., Tsunozaki, M., Hale, V.A., and Priess, J.R. (2002). APH-1 is a multiplass membrane protein essential for the Notch signaling pathway in Caenorhabditis elegans embryos. Proc. Natl Acad. Sci. USA. 99, 775-9. Abstract Article

Granato, M., Schnabel, H., and Schnabel, R. (1994). Genesis of an organ: molecular analysis of the pha-1 gene. Development 120, 3005-3017. Abstract

GuhaThakurta, D., Schriefer, L.A., Waterston, R.H., and Stormo, G.D. (2004). Novel transcription regulatory elements in Caenorhabditis elegans muscle genes. Genome Res. 14, 2457-2468. Abstract Article

GuhaThakurta, D., and Stormo, G.D. (2001). Identifying target sites for cooperatively binding factors. Bioinformatics 17, 608-621. Abstract

Harfe, B.D., Gomes, A.V., Kenyon, C., Liu, J., Krause, M., and Fire, A. (1998). Analysis of a Caenorhabditis elegans Twist homolog identifies conserved and divergent aspects of mesodermal patterning. Genes Dev. 12, 2623-2635. Abstract

Harris, T.J., and Peifer, M. (2004). Adherens junction-dependent and -independent steps in the establishment of epithelial cell polarity in Drosophila. J. Cell Biol. 167, 135-147. Abstract Article

Haun, C., Alexander, J., Stainier, D.Y., and Okkema, P.G. (1998). Rescue of Caenorhabditis elegans pharyngeal development by a vertebrate heart specification gene. Proc. Natl. Acad. Sci. U.S.A. 95, 5072-5075. Abstract Article

Heid, P.J., Raich, W.B., Smith, R., Mohler, W.A., Simokat, K., Gendreau, S.B., Rothman, J.H., and Hardin, J. (2001). The zinc finger protein DIE-1 is required for late events during epithelial cell rearrangement in $C$. elegans. Dev. Biol. 236, 165-180. Abstract Article

Hobson, R.J., Geng, J., Gray, A.D., and Komuniecki, R.W. (2003). SER-7b, a constitutively active Galphas coupled 5-HT7-like receptor expressed in the Caenorhabditis elegans M4 pharyngeal motorneuron. J. Neurochem. 87, 22-29. Abstract Article

Hope, I.A. (1991). "Promoter trapping" in Caenorhabditis elegans. Development 113, 399-408. Abstract

Horner, M.A., Quintin, S., Domeier, M.E., Kimble, J., Labouesse, M., and Mango, S.E. (1998). pha-4, an HNF-3 homologue, specifies pharyngeal organ identity in Caenorhabditis elegans. Genes Dev. 12, 1947-1952. Abstract

Huber, B.R., and Bulyk, M.L. (2006). Meta-analysis discovery of tissue-specific DNA sequence motifs from mammalian gene expression data. BMC Bioinformatics 7, 229. Abstract Article

Hutter, H., and Schnabel, R. (1994). glp-1 and inductions establishing embryonic axes in C. elegans. Development 120, 2051-2064. Abstract

Jenkins, N., Saam, J.R., and Mango, S.E. (2006). CYK-4/GAP Provides a Localized Cue to Initiate Anteroposterior Polarity upon Fertilization. Science 313, 1298-1301. Abstract Article

Jenna, S., Caruso, M.E., Emadali, A., Nguyen, D.T., Dominguez, M., Li, S., Roy, R., Reboul, J., Vidal, M., Tzimas, G.N., et al. (2005). Regulation of membrane trafficking by a novel Cdc42-related protein in Caenorhabditis elegans epithelial cells. Mol. Biol. Cell 16, 1629-1639. Abstract Article 
Kalb, J.M., Beaster-Jones, L., Fernandez, A.P., Okkema, P.G., Goszczynski, B., and McGhee, J.D. (2002). Interference between the PHA-4 and PEB-1 transcription factors in formation of the Caenorhabditis elegans pharynx. J. Mol. Biol. 320, 697-704. Abstract Article

Kalb, J.M., Lau, K.K., Goszczynski, B., Fukushige, T., Moons, D., Okkema, P.G., and McGhee, J.D. (1998). pha-4 is Ce-fkh-1, a fork head/HNF-3alpha, beta, gamma homolog that functions in organogenesis of the C. elegans pharynx. Development 125, 2171-2180. Abstract

Kaltenbach, L.S., Updike, D.L., and Mango, S.E. (2005). Contribution of the amino and carboxyl termini for PHA-4/FoxA function in Caenorhabditis elegans. Dev. Dyn. 234, 346-354. Abstract Article

Kellerman, S., Moore, J.A., Zierhut, W., Zimmer, H.G., Campbell, J., and Gerdes, A.M. (1992). Nuclear DNA content and nucleation patterns in rat cardiac myocytes from different models of cardiac hypertrophy. J. Mol. Cell. Cardiol. 24, 497-505. Abstract Article

Kiefer, J.C., Smith, P.A., and Mango, S.E. (2006). PHA-4/FoxA cooperates with TAM-1/TRIM to regulate cell fate restriction in the C. elegans foregut. Dev. Biol. in press.

Knuppel, R., Dietze, P., Lehnberg, W., Frech, K., and Wingender, E. (1994). TRANSFAC retrieval program: a network model database of eukaryotic transcription regulating sequences and proteins. J. Comput. Biol. 1, 191-198. Abstract

Knust, E., and Bossinger, O. (2002). Composition and formation of intercellular junctions in epithelial cells. Science 298, 1955-1959. Abstract Article

Koh, K., Peyrot, S.M., Wood, C.G., Wagmaister, J.A., Maduro, M.F., Eisenmann, D.M., and Rothman, J.H. (2002). Cell fates and fusion in the C. elegans vulval primordium are regulated by the EGL-18 and ELT-6 GATA factors apparent direct targets of the LIN-39 Hox protein. Development 129, 5171-5180. Abstract

Koh, K., and Rothman, J.H. (2001). ELT-5 and ELT-6 are required continuously to regulate epidermal seam cell differentiation and cell fusion in C. elegans. Development 128, 2867-2880. Abstract

Koppen, M., Simske, J.S., Sims, P.A., Firestein, B.L., Hall, D.H., Radice, A.D., Rongo, C., and Hardin, J.D. (2001). Cooperative regulation of AJM-1 controls junctional integrity in Caenorhabditis elegans epithelia. Nat. Cell Biol. 3, 983-991. Abstract Article

Kuchenthal, C.A., Chen, W., and Okkema, P.G. (2001). Multiple enhancers contribute to expression of the NK-2 homeobox gene ceh-22 in C. elegans pharyngeal muscle. Genesis 31,156-166. Abstract Article

Labouesse, M., and Mango, S.E. (1999). Patterning the C. elegans embryo: moving beyond the cell lineage. Trends Genet. 15, 307-313. Abstract Article

Lambie, E.J., and Kimble, J. (1991). Two homologous regulatory genes, lin-12 and glp-1, have overlapping functions. Development 112, 231-240. Abstract

Landmann, F., Quintin, S., and Labouesse, M. (2004). Multiple regulatory elements with spatially and temporally distinct activities control the expression of the epithelial differentiation gene lin-26 in C. elegans. Dev. Biol. 265, 478-490. Abstract Article

Legouis, R., Gansmuller, A., Sookhareea, S., Bosher, J.M., Baillie, D.L., and Labouesse, M. (2000). LET-413 is a basolateral protein required for the assembly of adherens junctions in Caenorhabditis elegans. Nat. Cell Biol. 2, 415-422. Abstract Article

Leung, B., Hermann, G.J., and Priess, J.R. (1999). Organogenesis of the Caenorhabditis elegans intestine. Dev. Biol. 216, 114-134. Abstract Article

Li, S., Armstrong, C.M., Bertin, N., Ge, H., Milstein, S., Boxem, M., Vidalain, P.O., Han, J.D., Chesneau, A., Hao, T., et al. (2004). A map of the interactome network of the metazoan C. elegans. Science 303, 540-543. Abstract Article 
The C. elegans pharynx: a model for organogenesis

Lin, R., Thompson, S., and Priess, J.R. (1995). pop-1 encodes an HMG box protein required for the specification of a mesoderm precursor in early C. elegans embryos. Cell 83, 599-609. Abstract Article

Liu, X., Brutlag, D.L., and Liu, J.S. (2001). BioProspector: discovering conserved DNA motifs in upstream regulatory regions of co-expressed genes. Pac. Symp. Biocomput. 127-138. Abstract

Liu, Y., Liu, X.S., Wei, L., Altman, R.B., and Batzoglou, S. (2004). Eukaryotic regulatory element conservation analysis and identification using comparative genomics. Genome Res. 14, 451-458. Abstract Article

Lo, M.C., Gay, F., Odom, R., Shi, Y., and Lin, R. (2004). Phosphorylation by the beta-catenin/MAPK complex promotes 14-3-3-mediated nuclear export of TCF/POP-1 in signal-responsive cells in C. elegans. Cell 117, 95-106. Abstract Article

Longabaugh, W.J., Davidson, E.H., and Bolouri, H. (2005). Computational representation of developmental genetic regulatory networks. Dev. Biol. 283, 1-16. Abstract Article

Maduro, M.F., Broitman-Maduro, G., Mengarelli, I., and Rothman, J.H. (2006). Maternal deployment of the embryonic SKN-1 to MED-1,2 cell specification pathway in C. elegans. Dev. Biol. in press. Abstract Article

Maduro, M.F., Hill, R.J., Heid, P.J., Newman-Smith, E.D., Zhu, J., Priess, J.R., and Rothman, J.H. (2005a). Genetic redundancy in endoderm specification within the genus Caenorhabditis. Dev. Biol. 284, 509-522. Abstract Article

Maduro, M.F., Kasmir, J.J., Zhu, J., and Rothman, J.H. (2005b). The Wnt effector POP-1 and the PAL-1/Caudal homeoprotein collaborate with SKN-1 to activate C. elegans endoderm development. Dev. Biol. 285, 510-523. Abstract Article

Maduro, M.F., Lin, R., and Rothman, J.H. (2002). Dynamics of a Developmental Switch: Recursive Intracellular and Intranuclear Redistribution of Caenorhabditis elegans POP-1 Parallels Wnt-Inhibited Transcriptional Repression. Dev. Biol. 248, 128-142. Abstract Article

Maduro, M.F., Meneghini, M.D., Bowerman, B., Broitman-Maduro, G., and Rothman, J.H. (2001). Restriction of mesendoderm to a single blastomere by the combined action of SKN-1 and a GSK-3 beta homolog is mediated by MED-1 and -2 in C. elegans. Mol. Cell 7, 475-485. Abstract Article

Mango, S.E., Lambie, E.J., and Kimble, J. (1994). The pha-4 gene is required to generate the pharyngeal primordium of Caenorhabditis elegans. Development 120, 3019-3031. Abstract

Mann, R.S., and Carroll, S.B. (2002). Molecular mechanisms of selector gene function and evolution. Curr. Opin. Genet. Dev. 12, 592-600. Abstract Article

McKay, J.P., Raizen, D.M., Gottschalk, A., Schafer, W.R., and Avery, L. (2004). eat-2 and eat-18 are required for nicotinic neurotransmission in the Caenorhabditis elegans pharynx. Genetics 166, 161-169. Abstract Article

McKeown, C., Praitis, V., and Austin, J. (1998). sma-1 encodes a betaH-spectrin homolog required for Caenorhabditis elegans morphogenesis. Development 125, 2087-2098. Abstract

McMahon, L., Legouis, R., Vonesch, J.L., and Labouesse, M. (2001). Assembly of C. elegans apical junctions involves positioning and compaction by LET-413 and protein aggregation by the MAGUK protein DLG-1. J. Cell. Sci. 114, 2265-2277. Abstract

Mohler, W.A., Shemer, G., del Campo, J.J., Valansi, C., Opoku-Serebuoh, E., Scranton, V., Assaf, N., White, J.G., and Podbilewicz, B. (2002). The type I membrane protein EFF-1 is essential for developmental cell fusion. Dev. Cell 2, 355-362. Abstract Article

Mootha, V.K., Lindgren, C.M., Eriksson, K.F., Subramanian, A., Sihag, S., Lehar, J., Puigserver, P., Carlsson, E., Ridderstrale, M., Laurila, E., et al. (2003). PGC-1alpha-responsive genes involved in oxidative phosphorylation are coordinately downregulated in human diabetes. Nat. Genet. 34, 267-273. Abstract Article 
Morck, C., Rauthan, M., Wagberg, F., and Pilon, M. (2004), pha-2 encodes the C. elegans ortholog of the homeodomain protein HEX and is required for the formation of the pharyngeal isthmus. Dev. Biol. 272, 403-418. Abstract Article

Moskowitz, I.P., Gendreau, S.B., Rothman, J.H. (1994). Combinatorial specification of blastomere identity by glp-1-dependent cellular interactions in the nematode Caenorhabditis elegans. Development 120, 3325-3338. Abstract

Muriel, J.M., Dong, C., Hutter, H., and Vogel, B.E. (2005). Fibulin-1C and Fibulin-1D splice variants have distinct functions and assemble in a hemicentin-dependent manner. Development 132, 4223-4234. Abstract Article

Naiche, L.A., Harrelson, Z., Kelly, R.G., and Papaioannou, V.E. (2005). T-box genes in vertebrate development. Annu. Rev. Genet. 39, 219-239. Abstract Article

Neves, A., and Priess, J.R. (2005). The REF-1 family of bHLH transcription factors pattern C. elegans embryos through Notch-dependent and Notch-independent pathways. Dev. Cell 8, 867-879. Abstract Article

Norman, K.R., and Moerman, D.G. (2002). Alpha spectrin is essential for morphogenesis and body wall muscle formation in Caenorhabditis elegans. J. Cell Biol. 157, 665-677. Abstract Article

Okkema, P.G., and Fire, A. (1994). The Caenorhabditis elegans NK-2 class homeoprotein CEH-22 is involved in combinatorial activation of gene expression in pharyngeal muscle. Development 120,2175-2186. Abstract

Okkema, P.G., Ha, E., Haun, C., Chen, W., and Fire, A. (1997). The Caenorhabditis elegans NK-2 homeobox gene ceh-22 activates pharyngeal muscle gene expression in combination with pha-1 and is required for normal pharyngeal development. Development 124, 3965-3973. Abstract

Okkema, P.G., Harrison, S.W., Plunger, V., Aryana, A., and Fire, A. (1993). Sequence requirements for myosin gene expression and regulation in Caenorhabditis elegans. Genetics 135, 385-404. Abstract

Park, M., Lewis, C., Turbay, D., Chung, A., Chen, J.N., Evans, S., Breitbart, R.E., Fishman, M.C., Izumo, S., and Bodmer, R. (1998). Differential rescue of visceral and cardiac defects in Drosophila by vertebrate tinman-related genes. Proc. Natl. Acad. Sci. U.S.A. 95, 9366-9371. Abstract Article

Penela, P., Murga, C., Ribas, C., Tutor, A.S., Peregrin, S., and Mayor, F., Jr. (2006). Mechanisms of regulation of G protein-coupled receptor kinases (GRKs) and cardiovascular disease. Cardiovasc. Res. 69, 46-56. Abstract Article

Pettitt, J., Wood, W.B., and Plasterk, R.H. (1996). $c d h-3$, a gene encoding a member of the cadherin superfamily, functions in epithelial cell morphogenesis in Caenorhabditis elegans. Development 122, 4149-4157. Abstract

Philippakis, A.A., He, F.S., and Bulyk, M.L. (2005). Modulefinder: a tool for computational discovery of cis regulatory modules. Pac. Symp. Biocomput. 519-530. Abstract

Pocock, R., Ahringer, J., Mitsch, M., Maxwell, S., and Woollard, A. (2004). A regulatory network of T-box genes and the even-skipped homologue vab-7 controls patterning and morphogenesis in C. elegans. Development 131, 2373-2385. Abstract Article

Portereiko, M.F., and Mango, S.E. (2001). Early morphogenesis of the Caenorhabditis elegans pharynx. Dev. Biol. 233, 482-494. Abstract Article

Portereiko, M.F., Saam, J., and Mango, S.E. (2004). ZEN-4/MKLP1 is required to polarize the foregut epithelium. Curr. Biol. 14, 932-941. Abstract Article

Priess, J.R., Schnabel, H., and Schnabel, R. (1987). The glp-l locus and cellular interactions in early C. elegans embryos. Cell 51,601-611. Abstract Article

Priess, J.R., and Thomson, J.N. (1987). Cellular interactions in early C. elegans embryos. Cell 48, 241-250. Abstract Article 
Qiu, X., and Fay, D.S. (2006). ARI-1, an RBR family ubiquitin-ligase, functions with UBC-18 to regulate pharyngeal development in C. elegans. Dev. Biol. 291, 239-252. Abstract Article

Raizen, D.M., and Avery, L. (1994). Electrical activity and behavior in the pharynx of Caenorhabditis elegans. Neuron 12, 483-495. Abstract Article

Raizen, D.M., Lee, R.Y., and Avery, L. (1995). Interacting genes required for pharyngeal excitation by motor neuron MC in Caenorhabditis elegans. Genetics 141, 1365-1382. Abstract

Rebay, I., Silver, S.J., and Tootle, T.L. (2005). New vision from Eyes absent: transcription factors as enzymes. Trends Genet. 21, 163-171. Abstract Article

Roy Chowdhury, S., Crum, T., Woollard, A., Aslam, S., and Okkema, P.G. (2006). The T-box factor TBX-2 and the SUMO conjugating enzyme UBC-9 are required for ABa-derived pharyngeal muscle in C. elegans. Dev. Biol. 95, 664-77 Article

Salkoff, L., Wei, A.D., Baban, B., Butler, A., Fawcett, G., Ferreira, G., and Santi, C.M. (2005). Potassium channels in C. elegans, In WormBook, T.C. e.R. Community, ed.

Sandelin, A., Wasserman, W.W., and Lenhard, B. (2004). ConSite: web-based prediction of regulatory elements using cross-species comparison. Nucleic Acids Res. 32, W249-W252. Abstract Article

Schmid, C., Schwarz, V., and Hutter, H. (2006). AST-1, a novel ETS-box transcription factor, controls axon guidance and pharynx development in C. elegans. Dev. Biol. 293, 403-413. Abstract Article

Schnabel, H., and Schnabel, R. (1990). An organ-specific differentiation gene, pha-1, from Caenorhabditis elegans. Science 250, 686-688. Article

Shannon, P., Markiel, A., Ozier, O., Baliga, N.S., Wang, J.T., Ramage, D., Amin, N., Schwikowski, B., and Ideker, T. (2003). Cytoscape: a software environment for integrated models of biomolecular interaction networks. Genome Res. 13, 2498-2504. Abstract Article

Shemer, G., Suissa, M., Kolotuev, I., Nguyen, K.C., Hall, D.H., and Podbilewicz, B. (2004). EFF-1 is sufficient to initiate and execute tissue-specific cell fusion in C. elegans. Curr. Biol. 14, 1587-1591. Abstract Article

Shetty, P., Lo, M.C., Robertson, S.M., and Lin, R. (2005). C. elegans TCF protein, POP-1, converts from repressor to activator as a result of Wnt-induced lowering of nuclear levels. Dev. Biol. 285, 584-592. Abstract Article

Shimono, Y., Murakami, H., Kawai, K., Wade, P.A., Shimokata, K., and Takahashi, M. (2003). Mi-2 beta associates with BRG1 and RET finger protein at the distinct regions with transcriptional activating and repressing abilities. J. Biol. Chem. 278, 51638-51645. Abstract Article

Shtonda, B., and Avery, L. (2005). CCA-1, EGL-19 and EXP-2 currents shape action potentials in the Caenorhabditis elegans pharynx. J. Exp. Biol. 208, 2177-2190. Abstract Article

Simske, J.S., and Hardin, J. (2001). Getting into shape: epidermal morphogenesis in Caenorhabditis elegans. Bioessays 23, 12-23. Abstract

Smith, P.A., and Mango, S.E. (2006). Role of T box gene $t b x-2$ for anterior foregut muscle development in $C$. elegans. Dev. Biol. in press. Abstract Article

Starich, T.A., Lee, R.Y., Panzarella, C., Avery, L., and Shaw, J.E. (1996). eat-5 and unc-7 represent a multigene family in Caenorhabditis elegans involved in cell-cell coupling. J. Cell Biol. 134, 537-548. Abstract Article

Starich, T.A., Miller, A., Nguyen, R.L., Hall, D.H., and Shaw, J.E. (2003). The Caenorhabditis elegans innexin INX-3 is localized to gap junctions and is essential for embryonic development. Dev. Biol. 256, 403-417. Abstract Article 
The C. elegans pharynx: a model for organogenesis

Steger, K.A., and Avery, L. (2004). The GAR-3 muscarinic receptor cooperates with calcium signals to regulate muscle contraction in the Caenorhabditis elegans pharynx. Genetics 167, 633-643. Abstract Article

Storfer-Glazer, F.A., and Wood, W.B. (1994). Effects of chromosomal deficiencies on early cleavage patterning and terminal phenotype in Caenorhabditis elegans embryos. Genetics 137, 499-508. Abstract

Sulston, J.E., Schierenberg, E., White, J.G., and Thomson, J.N. (1983). The embryonic cell lineage of the nematode Caenorhabditis elegans. Dev. Biol. 100, 64-119. Abstract Article

Terns, R.M., Kroll-Conner, P., Zhu, J., Chung, S., and Rothman, J.H. (1997). A deficiency screen for zygotic loci required for establishment and patterning of the epidermis in Caenorhabditis elegans. Genetics 146, 185-206. Abstract

Thatcher, J.D., Fernandez, A.P., Beaster-Jones, L., Haun, C., and Okkema, P.G. (2001). The Caenorhabditis elegans peb-1 gene encodes a novel DNA-binding protein involved in morphogenesis of the pharynx, vulva, and hindgut. Dev. Biol. 229, 480-493. Abstract Article

Towers, P.R., Edwards, B., Richmond, J.E., and Sattelle, D.B. (2005). The Caenorhabditis elegans lev-8 gene encodes a novel type of nicotinic acetylcholine receptor alpha subunit. J. Neurochem. 93, 1-9. Abstract Article

Updike, D.L. and Mango, S.E. (2006). Temporal Regulation of Foregut Development by HTZ-1/H2A.Z and PHA-4/FoxA. PLoS Genet. 2, e161. Abstract Article

van Helden, J. (2003). Regulatory sequence analysis tools. Nucleic Acids Res. 31, 3593-3596. Abstract Article

Vilimas, T., Abraham, A., and Okkema, P.G. (2004). An early pharyngeal muscle enhancer from the Caenorhabditis elegans ceh-22 gene is targeted by the Forkhead factor PHA-4. Dev. Biol. 266, 388-398. Abstract Article

Vlieghe, D., Sandelin, A., De Bleser, P.J., Vleminckx, K., Wasserman, W.W., van Roy, F., and Lenhard, B. (2006). A new generation of JASPAR, the open-access repository for transcription factor binding site profiles. Nucleic Acids Res. 34, D95-97. Abstract Article

Williams, B.D., and Waterston, R.H. (1994). Genes critical for muscle development and function in Caenorhabditis elegans identified through lethal mutations. J. Cell Biol. 124, 475-490. Abstract Article

Wilson, V., and Conlon, F.L. (2002). The T-box family. Genome. Biol. 3, REVIEWS3008. Abstract Article

Yanowitz, J.L., Shakir, M.A., Hedgecock, E., Hutter, H., Fire, A.Z., and Lundquist, E.A. (2004). UNC-39, the $C$. elegans homolog of the human myotonic dystrophy-associated homeodomain protein Six5, regulates cell motility and differentiation. Dev. Biol. 272, 389-402. Abstract Article

Young, J.M., and Hope, I.A. (1993). Molecular markers of differentiation in Caenorhabditis elegans obtained by promoter trapping. Dev. Dyn. 196, 124-132. Abstract Article

Zaret, K.S. (2002). Regulatory phases of early liver development: paradigms of organogenesis. Nat. Rev. Genet. 3, 499-512. Abstract Article

Zhu, J., Fukushige, T., McGhee, J.D., and Rothman, J.H. (1998). Reprogramming of early embryonic blastomeres into endodermal progenitors by a Caenorhabditis elegans GATA factor. Genes Dev. 12, 3809-3814. Abstract

All WormBook content, except where otherwise noted, is licensed under a Creative Commons Attribution License. 